Article

\title{
Expression Profile of Diabetes-Related Genes Associated with Leukocyte Sirtuin 1 Overexpression in Gestational Diabetes
}

\author{
Katarzyna Mac-Marcjanek ${ }^{1}$, Andrzej Zieleniak ${ }^{1}{ }^{1}$, Monika Zurawska-Klis ${ }^{2}$, \\ Katarzyna Cypryk ${ }^{2}$ (D), Lucyna Wozniak ${ }^{1, *(1)}$ and Marzena Wojcik $1, * \mathbb{D}$ \\ 1 Department of Structural Biology, Faculty of Biomedical Sciences and Postgraduate Education, \\ Medical University of Lodz, 90-752 Lodz, Poland; k.mac.marcjanek@gmail.com (K.M.-M.); \\ andrzej.zieleniak@umed.lodz.pl (A.Z.) \\ 2 Diabetology and Metabolic Diseases Department, Medical University of Lodz, 92-213 Lodz; \\ monika.zurawska-klis@umed.lodz.pl (M.Z.-K.); katarzyna.cypryk@umed.lodz.pl (K.C.) \\ * Correspondence: lucyna.wozniak@umed.lodz.pl (L.W.); marzena.wojcik@umed.lodz.pl (M.W.); \\ Tel.: +48-426-393-238 (L.W. \& M.W.)
}

Received: 29 September 2018; Accepted: 28 November 2018; Published: 30 November 2018

\begin{abstract}
Although compelling evidence indicates that Sirtuin 1 (SIRT1) plays a prominent role in type 2 diabetes, its relationship with gestational diabetes (GDM) remains elusive. This study was aimed at identifying diabetes-related genes and cellular pathways linked to changes of leukocyte SIRT1 expression at the time of GDM diagnosis. For this purpose, 122 GDM patients were screened for leukocyte SIRT1 expression, and two subgroups were distinguished, namely GDM/SIRT1( $\uparrow)$ $(n=30, p<0.05)$ and GDM $/ \operatorname{SIRT1}(\leftrightarrow)(n=92, p>0.05)$, with significant and insignificant changes in leukocyte SIRT1 expression compared to a normal glucose tolerant (NGT) group $(n=41)$, respectively. PCR array analysis identified 11 diabetes-related genes with at least a \pm 2 -fold difference in expression in GDM/SIRT1( $\uparrow)$ patients $(n=9)$ vs. NGT controls $(n=7)$; in addition, significant differences in the expression of four of the six investigated genes were confirmed between the entire GDM/SIRT1( $\uparrow)$ group and the whole NGT group $(p<0.05)$. Interestingly, of these four genes, only ACLY expression was found to significantly differ between GDM/SIRT1( $\uparrow)$ and GDM/SIRT1 $(\leftrightarrow)$. This study demonstrates that under hyperglycemic conditions, leukocyte SIRT1 overexpression is accompanied by an over-abundance of three transcripts and an under-abundance of another; these four govern related metabolism, inflammation, and transport functions, suggesting that such alterations might represent systemic biological adaptations with a unique $A C L Y$ under-expression in GDM/SIRT1(个) women.
\end{abstract}

Keywords: gene expression; gestational diabetes mellitus (GDM); Ingenuity Pathway Analysis (IPA); PCR array; Sirtuin 1 (SIRT1)

\section{Introduction}

Gestational diabetes mellitus (GDM), defined as a carbohydrate intolerance of varying severity with onset or first recognition during pregnancy, is one of the most common pregnancy complications, affecting between $3 \%$ and $17 \%$ of all pregnancies, depending on the population studied and the diagnostic criteria used [1]. Its occurrence is associated with an increased risk of adverse maternal and perinatal outcomes, including preeclampsia, preterm delivery, Cesarean section, macrosomia, and respiratory distress syndrome [2]. Additionally, patients with GDM are more prone to developing type 2 diabetes mellitus (T2DM) and cardiovascular disease later in life than non-diabetic subjects and 
their offspring are also at an increased risk of developing obesity, metabolic syndrome, and T2DM during childhood and adolescence [3,4].

GDM and T2DM share some common features underlying pathophysiology. Both disorders are characterized by peripheral insulin resistance combined with a relative insufficiency in pancreatic beta-cell insulin production. Although there is no consensus in the pathophysiology of GDM, an altered adipokine metabolism, pro-inflammatory state, and exaggerated oxidative stress have been identified as important contributors [5-8].

Silent mating type information regulation 2 homolog 1 (SIRT1), a nicotine adenine dinucleotide (NAD+)-dependent class III protein deacetylase, is currently considered as a powerful regulator of cellular metabolism. It is believed to act as a pivotal mediator in coordinating metabolic responses to nutritional availability; hence, changes in its expression are believed to be associated with many pathological conditions, with diabetes being one of them.

It has been well-documented that SIRT1 increases insulin sensitivity in major insulin sensitive tissues, such as liver, skeletal muscle, and adipose tissue, and induces insulin secretion by pancreatic beta-cells $[9,10]$. Moreover, several studies have shown that Sirt1 overexpression protects animals against high fat diet (HFD)-induced glucose resistance [11,12], whereas SIRT1 down-regulation is associated with impaired glucose tolerance in individuals with metabolic syndrome and T2DM [13,14]. Similarly, pharmacological stimulation of SIRT1 by sirtuin-activating compounds (STACs), such as resveratrol, SRT1720, and SRT2104, has been reported to protect against HFD-induced obesity and insulin resistance in animals and humans [15-18]. However, it remains uncertain whether resveratrol and SRT1720 may activate SIRT1 directly [19]. It is noteworthy that despite these promising results, it has been found that patients with well-controlled T2DM who received $150 \mathrm{mg} /$ day resveratrol for 30 days failed to demonstrate any improvement in hepatic or peripheral insulin sensitivity [20]. In addition, some reports have revealed decreased blood glucose levels in Sirt1 knockout mice compared to wild-type mice [21], and increased glucose production by cultured rat hepatoma cells after treatment with resveratrol [22].

Despite the fact that SIRT1 is increasingly being recognized for its growing number of biological roles in T2DM, much remains to be learned about the pathophysiologic implications of SIRT1-dependent alterations in GDM. To date, no systematic studies of SIRT1 expression under diabetic pregnancy have been performed, although some reports in this field have demonstrated disease-related alterations in the SIRT1 level. For example, GDM and in vitro hyperglycemia were found to decrease SIRT1 production in fetal endothelial colony-forming cells (ECFCs) and human umbilical vein endothelial cells (HUVECs) [23], while resveratrol was shown to impair GDM symptoms, such as hyperglycemia and insulin resistance, in the $d b /+$ genetic GDM mouse model [24]. On the other hand, a more recent study showed increased SIRT1 expression at one day postpartum in GDM women as a consequence of their exposure to hyperglycemia during GDM [25].

The present study examines GDM-induced molecular changes associated with increased SIRT1 mRNA expression in leukocytes at the time of GDM diagnosis. In the initial stage, GDM patients were screened for leukocyte SIRT1 expression. Since GDM and T2DM share an underlying pathophysiology, suggesting that a striking parallel may exist between these two diseases on the genetic level, the following stages went on to investigate specific changes in diabetes-relevant genes in the leukocytes of GDM patients with SIRT1 overexpression. These analyses were performed using Reverse Transcriptase-quantitative Polymerase Chain Reaction (RT-qPCR) array technology: a powerful molecular tool used for simultaneously investigating gene expression in various tissues, including the blood [26]. To explore possible mechanisms of action for the identified gene candidates, an analysis was performed of gene networks and pathways by Ingenuity Pathway Analysis (IPA). Peripheral blood leukocytes were chosen for analyzing the expression of SIRT1 and diabetes-related genes in pregnancies with GDM and those with normal glucose tolerance (NGT) since these cells are able to reflect pathological changes occurring in different tissues of the body: their use has been recommended in exploratory studies where metabolic tissues are not available, as in the case of pregnant women [27]. 


\section{Results}

\subsection{Differential Clinical Characteristics and Leukocyte SIRT1 Gene Expression in the Studied Groups}

The clinical data and leukocyte SIRT1 expression data for different experimental groups are listed in Table 1. The univariate correlations between the leukocyte SIRT1 mRNA and baseline characteristics of the subgroups studied are presented in Table 2.

Table 1. Clinical and leukocyte SIRT1 mRNA expression data for different experimental groups.

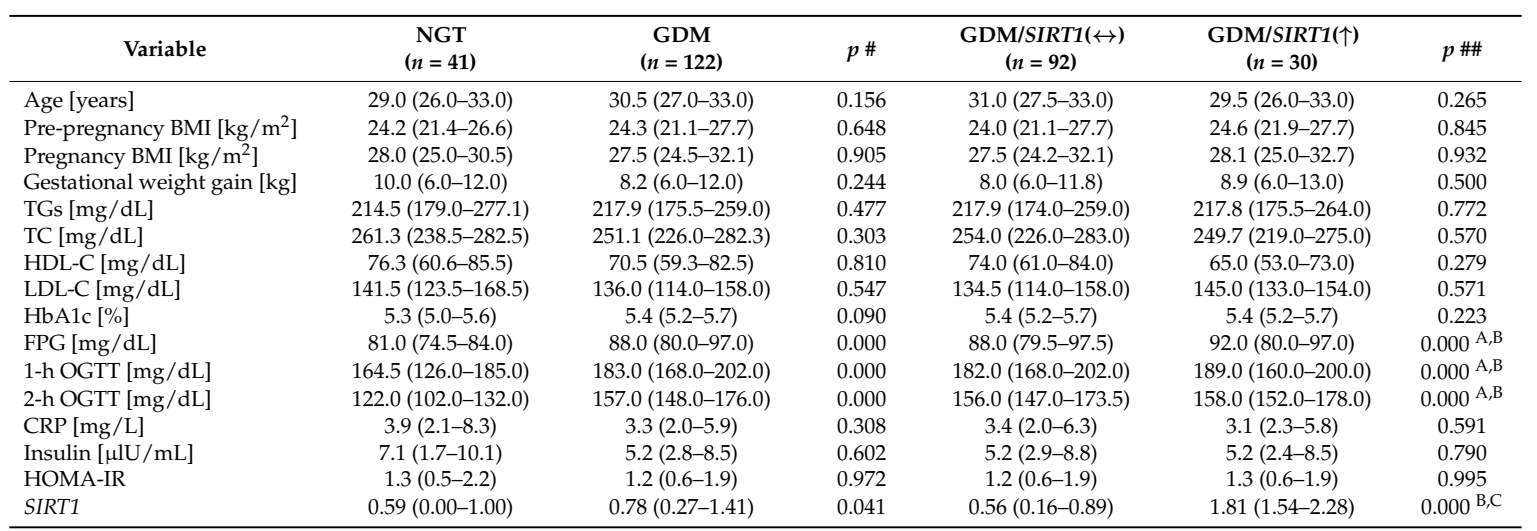

Abbreviations: BMI, body mass index; CRP, C reactive protein; FPG, fasting plasma glucose; HDL, high-density lipoprotein; HOMA-IR, homeostasis model assessment of insulin resistance; LDL, low density lipoprotein; TC, total cholesterol; TGs, triglycerides. Data are presented as median and interquartile range (25-75 percentiles). \# $p$ values assessed by Wilcoxon's test; \#\# $p$ values between NGT, GDM/SIRT1( $\leftrightarrow)$, and GDM/SIRT1( $\uparrow$ ) groups assessed by Kruskal-Wallis' test; $p<0.05$ GDM/SIRT1( $\leftrightarrow$ ) vs. NGT groups (A), GDM/SIRT1( $\uparrow$ ) vs. NGT groups $(\mathrm{B})$, and GDM/SIRT1 $(\leftrightarrow)$ vs. GDM/SIRT1( $\uparrow)$ groups (C) as assessed by post hoc pairwise multiple comparisons of mean rank sums.

Table 2. Spearman correlation analysis of leukocyte SIRT1 gene expression with clinical parameters in the entire study groups.

\begin{tabular}{|c|c|c|c|c|c|c|}
\hline \multirow[t]{2}{*}{ Variable } & \multicolumn{2}{|c|}{$\begin{array}{c}\text { NGT+GDM } \\
(n=163)\end{array}$} & \multicolumn{2}{|c|}{$\begin{array}{c}\mathrm{NGT}+\mathrm{GDM} / \mathrm{SIRT} 1(\leftrightarrow) \\
(n=133)\end{array}$} & \multicolumn{2}{|c|}{$\begin{array}{c}\mathrm{NGT}+\mathrm{GDM} / \mathrm{SIRT1}(\uparrow) \\
(n=71)\end{array}$} \\
\hline & $R(95 \% \mathrm{CI})$ & $p$ & $R(95 \% \mathrm{CI})$ & $p$ & $R(95 \% \mathrm{CI})$ & $p$ \\
\hline Age [years] & $-0.03(-0.18,0.13)$ & 0.721 & $0.01(-0.16,0.18)$ & 0.938 & $-0.02(-0.25,0.22)$ & 0.888 \\
\hline Pre-pregnancy BMI $\left[\mathrm{kg} / \mathrm{m}^{2}\right]$ & $0.10(-0.05,0.25)$ & 0.197 & $0.12(-0.06,0.28)$ & 0.187 & $0.12(-0.11,0.35)$ & 0.325 \\
\hline Pregnancy BMI $\left[\mathrm{kg} / \mathrm{m}^{2}\right]$ & $0.04(-0.11,0.20)$ & 0.581 & $0.04(-0.14,0.21)$ & 0.679 & $0.07(-0.17,0.30)$ & 0.553 \\
\hline Gestational weight gain $[\mathrm{kg}]$ & $-0.12(-0.27,0.03)$ & 0.127 & $-0.16(-0.32,0.02)$ & 0.069 & $-0.12(-0.34,0.12)$ & 0.318 \\
\hline $\mathrm{TC}[\mathrm{mg} / \mathrm{dL}]$ & $-0.01(-0.20,0.19)$ & 0.919 & $0.03(-0.19,0.24)$ & 0.815 & $-0.02(-0.29,0.26)$ & 0.911 \\
\hline TGs [mg/dL] & $0.06(-0.14,0.25)$ & 0.575 & $0.09(-0.12,0.30)$ & 0.401 & $0.06(-0.22,0.33)$ & 0.695 \\
\hline $\mathrm{HDL}-\mathrm{C}[\mathrm{mg} / \mathrm{dL}]$ & $-0.17(-0.36,0.02)$ & 0.080 & $-0.10(-0.31,0.11)$ & 0.345 & $-0.25(-0.49,0.03)$ & 0.082 \\
\hline LDL-C $[\mathrm{mg} / \mathrm{dL}]$ & $-0.00(-0.20,0.19)$ & 0.969 & $-0.08(-0.29,0.14)$ & 0.474 & $0.01(-0.27,0.29)$ & 0.942 \\
\hline $\mathrm{HbA} 1 \mathrm{c}[\%]$ & $0.04(-0.12,0.20)$ & 0.616 & $0.03(-0.15,0.20)$ & 0.774 & $0.31(0.08,0.51)$ & 0.010 * \\
\hline $\mathrm{FPG}[\mathrm{mg} / \mathrm{dL}]$ & $0.07(-0.09,0.22)$ & 0.406 & $-0.03(-0.21,0.15)$ & 0.733 & $0.41(0.19,0.59)$ & 0.000 * \\
\hline 1-h OGTT $[\mathrm{mg} / \mathrm{dL}]$ & $-0.00(-0.17,0.17)$ & 0.993 & $-0.05(-0.24,0.14)$ & 0.615 & $0.32(0.06,0.53)$ & 0.015 * \\
\hline 2-h OGTT [mg/dL] & $0.23(0.07,0.37)$ & $0.005 *$ & $0.08(-0.09,0.25)$ & 0.368 & $0.76(0.64,0.85)$ & 0.000 * \\
\hline $\mathrm{CRP}[\mathrm{mg} / \mathrm{L}]$ & $-0.01(-0.18,0.16)$ & 0.922 & $0.04(-0.15,0.22)$ & 0.702 & $-0.01(-0.26,0.24)$ & 0.924 \\
\hline Insulin $[\mu \mathrm{lU} / \mathrm{mL}]$ & $-0.13(-0.29,0.04)$ & 0.138 & $-0.12(-0.30,0.07)$ & 0.196 & $-0.15(-0.38,0.10)$ & 0.233 \\
\hline HOMA-IR & $-0.08(-0.25,0.10)$ & 0.386 & $-0.11(-0.30,0.09)$ & 0.285 & $-0.06(-0.31,0.19)$ & 0.623 \\
\hline
\end{tabular}

BMI, body mass index; CRP, C-reactive protein; FPG, fasting blood glucose; HDL, high-density lipoprotein; HOMA-IR, homeostasis model assessment of insulin resistance; LDL, low-density lipoprotein; TC, total cholesterol; TGs, triglycerides. * $p<0.05$ as assessed by Spearman's rank order correlation analysis; $95 \%$ confidence interval (CI) for correlation coefficient.

\subsubsection{GDM Patients Versus Control Subjects}

As expected, women with GDM $(n=122)$ had higher FPG, 1-h, and 2-h plasma glucose concentrations during the OGTT $(p<0.001)$ compared to NGT controls $(n=41)$ (Table 1$)$. No significant difference was observed between the groups with respect to maternal age, degree of whole adiposity (i.e., the indices of pre-pregnancy and pregnancy BMI as well as body weight gain), lipid profile, (i.e., TGs, LDL-C, HDL-C, and TC), inflammatory marker (CRP) or insulin-resistance indices, such as plasma insulin level and HOMA-IR $(p>0.05)$. Interestingly, PCR analyses indicated that the 
leukocyte SIRT1 mRNA level was significantly higher in the hyperglycemic GDM group compared to the NGT group (1.32-fold difference between the groups; $p=0.041)$, even after adjusting for age and obesity parameters, such as pre- and pregnancy BMI and gestational body weight gain (Table 3). In leukocyte, SIRT1 gene expression showed a significant positive correlation with the 2-h post-load glucose concentration $(R=0.23, p=0.005)$ in the entire study group (GDM+NGT, $n=163)$. No other correlations were found between leukocyte SIRT1 mRNA and clinical variables (Table 2).

Table 3. ANCOVA analysis of leukocyte SIRT1 expression between the GDM and NGT groups (Status) with adjustment for age and obesity variables (pre- and pregnancy BMI and gestational weight gain).

\begin{tabular}{lcccc}
\hline \multicolumn{1}{c}{ Variable } & DF & MS & $\boldsymbol{F}$ & $p$ \\
\hline Age & 1 & 0.34 & 0.74 & 0.392 \\
Pre-pregnancy BMI & 1 & 0.11 & 0.24 & 0.627 \\
Pregnancy BMI & 1 & 0.15 & 0.32 & 0.574 \\
Gestational weight & 1 & 0.29 & 0.62 & 0.431 \\
gain & 1 & 2.17 & 4.72 & 0.031 \\
Status & &
\end{tabular}

$D F$, degrees of freedom; $F$, Fisher's test; $M S$, mean square; $p<0.05$ for analysis of covariance (ANCOVA) between two groups with adjustment for the corresponding variables.

\subsubsection{GDM/SIRT1(个) Patients Versus Control Subjects}

The GDM group ( $n=122)$ was stratified into the two subgroups, GDM/SIRT1( $\uparrow)(n=30)$ and GDM/SIRT1 $\leftrightarrow(n=92)$, based on the cut-off value for leukocyte SIRT1 mRNA given in Materials and Methods. The results of the Kruskal-Wallis test identified a significant difference between the three groups with regard to fasting and post-load glucose $(p<0.001)$ : GDM $/ \operatorname{SIRT1}(\uparrow), \operatorname{GDM} / \operatorname{SIRT1}(\leftrightarrow)$, and NGT $(p<0.05)$. The pairwise post hoc test for multiple comparisons revealed significantly higher fasting and post-load glucose concentrations in the two GDM subgroups compared to the NGT controls $(p<0.05)$. Although the values of these parameters were higher in the GDM/SIRT1( $\uparrow)$ group than the GDM/SIRT1 $(\leftrightarrow)$ group, they did not reach statistical significance $(p>0.05)$ (Table 1$)$.

As expected, the leukocyte SIRT1 expression was significantly higher in the GDM/SIRT1( $\uparrow)$ group than the GDM/SIRT1 $(\leftrightarrow)$ and NGT groups $(p<0.05)$, with a 3.23- and 3.07-fold up-regulation, respectively; however, the level was comparable between the GDM/SIRT1( $\leftrightarrow)$ and NGT groups $(p>0.05)$ (Table 1, Figure 1).

The univariate correlation analyses revealed significant positive associations between leukocyte SIRT1 gene expression and plasma glucose measurements at fasting $(R=0.41, p<0.001)$ and when following the OGTT ( $R=0.32, p=0.015$ and $R=0.76, p<0.001$ for 1-h and 2-h post-load glucose concentrations, respectively), as well as with plasma HbA1c level $(R=0.31, p=0.010)$ in the entire study group (NGT+ GDM/SIRT1( $\uparrow), n=71)$ (Table 2). 


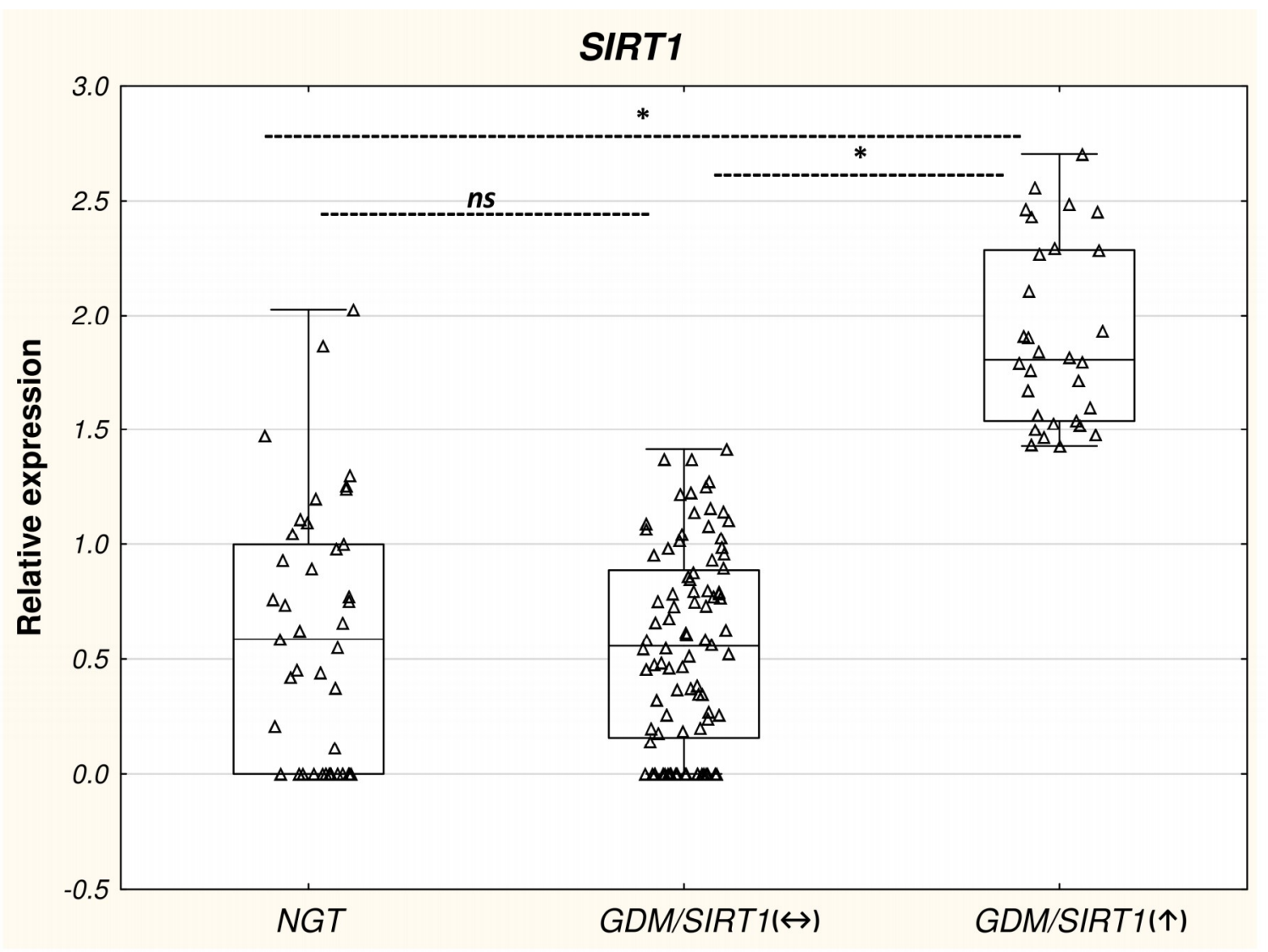

Figure 1. Comparison of leukocyte SIRT1 mRNA expression in the NGT $(n=41), \mathrm{GDM} / \operatorname{SIRT1}(\uparrow)$ $(n=30)$ and GDM/SIRT1 $(\leftrightarrow)(n=92)$ groups. Leukocyte SIRT1 mRNA level was normalized to a mean of the endogenous control GAPDH. Data are expressed as median \pm interquartile range $(25-75 \%),{ }^{*} p<0.05$ as assessed by post hoc test for pairwise multiple comparisons of mean rank sums; n.s.: non-significant.

\subsection{Differential mRNA Expression of Diabetes-Related Genes in Leukocytes from GDM/SIRT1( $\uparrow$ ) Patients Versus NGT Controls}

To identify a transcriptional signature associated with leukocyte SIRT1 overexpression, the Human Diabetes $\mathrm{RT}^{2}$ Profiler ${ }^{\mathrm{TM}}$ PCR Array was used to compare the expression profile of diabetes-related genes in leukocytes from hyperglycemic GDM/SIRT1( $\uparrow)$ patients $(n=9)$ with that of the NGT subjects $(n=7)$. As shown in Table S1, out of 84 diabetes-related genes broadly categorized into the six functional clusters according to the Qiagen list, as detailed in the Materials and Methods section, $68(80.1 \%)$ were detectable $(\mathrm{Ct}<35)$ via the PCR profiler array in leukocytes. Among these transcripts, four were up-regulated (SNAP23, G6PD, IL6, and IRS2) and seven were down-regulated (ACLY, GPD1, NSF, STXBP2, PDX1, SREBF1, and IRS1), with a two-fold or greater expression difference between the GDM/SIRT1( $\uparrow$ ) and NGT groups (Table 4). Out of the 11 differentially expressed genes in the GDM/SIRT1( $\uparrow)$ subjects, those encoding metabolic enzymes (ACLY, G6PD, GPD1) and molecules involved in receptor and molecular transport functions (NSF, SNAP23, STXBP2) represent the two dominant functional clusters (54.5\%). Other abnormally expressed genes were found to encode the transcription factors PDX1 and SREBF1, which are engaged in the regulation of insulin gene expression and lipid metabolism, respectively, as well as insulin receptor substrates IRS1 and IRS2 and pro-inflammatory cytokine IL6. 
Table 4. List of 11 diabetes-related genes with at least \pm 2 -fold regulation in leukocytes from the GDM/SIRT1( $\uparrow)$ pregnancies $(n=9)$ compared to the NGT controls $(n=7)$.

\begin{tabular}{|c|c|c|c|c|}
\hline Unigene & GenBank & Symbol & Description & FC \\
\hline & & & Receptors, Transporters \& Channels * & \\
\hline Hs, 431279 & NM_006178 & NSF & $\mathrm{N}$-ethylmaleimide-sensitive factor & 0.48 \\
\hline Hs,511149 & NM_003825 & SNAP23 & Synaptosomal-associated protein, $23 \mathrm{kDa}$ & 3.90 \\
\hline Hs, 515104 & NM_006949 & STXBP2 & $\begin{array}{l}\text { Syntaxin binding protein } 2 \\
\text { Metabolic Enzymes }\end{array}$ & 0.50 \\
\hline Hs,387567 & NM_001096 & $A C L Y$ & ATP citrate lyase & 0.48 \\
\hline $\mathrm{Hs}, 461047$ & NM_000402 & G6PD & Glucose-6-phosphate dehydrogenase & 2.81 \\
\hline Hs,524418 & NM_005276 & GPD1 & $\begin{array}{l}\text { Glycerol-3-phosphate dehydrogenase } 1 \text { (soluble) } \\
\text { Cytokines \& Growth Factors }\end{array}$ & 0.49 \\
\hline $\mathrm{Hs}, 654458$ & NM_000600 & IL6 & $\begin{array}{l}\text { Interleukin } 6 \text { (interferon, beta 2) } \\
\text { Signal Transduction }\end{array}$ & 2.07 \\
\hline $\mathrm{Hs}, 471508$ & NM_005544 & IRS1 & Insulin receptor substrate 1 & 0.49 \\
\hline $\mathrm{Hs}, 442344$ & NM_003749 & IRS2 & $\begin{array}{l}\text { Insulin receptor substrate } 2 \\
\text { Transcription Factors }\end{array}$ & 2.31 \\
\hline $\mathrm{Hs}, 32938$ & NM_000209 & PDX1 & Pancreatic and duodenal homeobox 1 & 0.33 \\
\hline $\mathrm{Hs}, 592123$ & NM_004176 & SREBF1 & $\begin{array}{l}\text { Sterol regulatory element binding transcription } \\
\text { factor } 1\end{array}$ & 0.32 \\
\hline
\end{tabular}

* Grouped according to function based on Qiagen listing. The fold changes (FC) are listed for each gene.

\subsection{Real-time PCR Verification of the Selected Genes Among Study Groups}

The next stage examined whether gene expression changes for the six selected genes with an FC of $<-2$ or $>2$ (SNAP23, G6PD, IL6, IRS2, ACLY, SREBF1) in the pooled RNA samples of the GDM/SIRT1( $\uparrow)$ patients in a PCR profiler array could be representative for this group in general. To achieve this, RT-qPCR was used to compare the expression levels of the six gene transcripts in the three groups: RNA samples $(n=30)$ from GDM/SIRT1( $\uparrow)$ individuals versus RNA samples $(n=90)$ from GDM $/ \operatorname{SIRT1}(\leftrightarrow)$ patients versus RNA samples $(n=41)$ from NGT subjects (Table 5 and Figure 2). The selected genes represented each of the five functional categories, including receptors and transporters (SNAP23), metabolic enzymes (ACLY, G6PD), secreted factors (IL6), signal transduction molecules (IRS2), and transcription factors (SREBF1). To make the findings more robust, the analysis employed different primers sets from those used in the PCR array (Table 8 in Materials and Methods). The gene expression analysis revealed that of the six selected genes, four demonstrated a significantly different expression between the GDM/SIRT1( $\uparrow)$ and the NGT group $(p<0.05)$ : ACLY $(\mathrm{FC}=0.63)$ displayed a significantly lower expression, while G6PD (FC = 1.52), IL6 (FC = 2.29), and SNAP23 (FC = 6.55) demonstrated a significantly increased expression. The other two genes, IRS2 (FC $=2.62)$ and SREBF1 $(\mathrm{FC}=0.34)$, were up-regulated and down-regulated in the GDM/SIRT1( $\uparrow$ ) group, respectively; however, these differences were not statistically significant $(p>0.05$, Table 5$)$. Importantly, the genes were found to be regulated in the same direction in both the pooled RNA (PCR array) and non-pooled RNA (RT-qPCR verification) samples of the GDM/SIRT1( $\uparrow$ ) patients. It is noteworthy that the FCs observed for four of the genes (ACLY, IL6, IRS2, SREBF1) were close to those obtained from the PCR array, whereas the FCs for G6PD and SNAP23 were approximately two times lower and higher, respectively, than those obtained from the PCR array.

When the expression of the six selected genes was compared between the GDM/SIRT1( $\leftrightarrow)$ and NGT groups, only IL6 was significantly increased in the GDM/SIRT1 $\leftrightarrow$ ) group (FC $=1.88 ; p<0.05)$; however, this increase was smaller than in the GDM/SIRT1( $\uparrow)$ group $(\mathrm{FC}=2.29 ; p<0.05)$. Of note, except the $A C L Y$ gene, all other genes were found to be regulated in the same direction as in the GDM/SIRT1( $\uparrow$ ) group (Table 5 and Figure 2). 
Table 5. Comparison of differences in gene expression between GDM and NGT for each of the six genes, as indicated by PCR array and RT-qPCR verification.

\begin{tabular}{|c|c|c|c|c|}
\hline \multirow{2}{*}{ Symbol } & \multirow{2}{*}{ Description } & \multirow{2}{*}{$\begin{array}{c}\text { PCR Array } \\
\text { GDM/SIRT1( } \uparrow \text { vs. NGT }\end{array}$} & \multicolumn{2}{|c|}{$R T-q P C R$ Verification } \\
\hline & & & GDM/SIRT1(个) vs. NGT & GDM/SIRT1(↔) vs. NGT \\
\hline \multirow[b]{2}{*}{ SNAP23 } & Receptors, Transporters \& Channels $\S$ & & & \\
\hline & Synaptosomal-associated protein, $23 \mathrm{kDa}$ & 3.90 & $6.55 *$ & 3.93 \\
\hline$A C L Y$ & ATP citrate lyase & 0.48 & $0.63 *$ & 1.11 \\
\hline \multirow[t]{2}{*}{ G6PD } & Glucose-6-phosphate dehydrogenase & 2.81 & $1.52 *$ & 1.06 \\
\hline & Cytokines \& Growth Factors & & & \\
\hline IL6 & Interleukin 6 (interferon, beta 2) & 2.07 & $2.28 *$ & $1.88^{*}$ \\
\hline IRS2 & Transcription Factors & & & \\
\hline SREBF1 & Sterol regulatory element binding transcription factor 1 & 0.32 & 0.33 & 0.68 \\
\hline
\end{tabular}

$\S$ Grouped according to function based on Qiagen listing. ${ }^{*} p<0.05$ as assessed by Kruskal-Wallis test followed by post hoc pairwise multiple comparisons. The fold changes (FC) are listed for each gene.
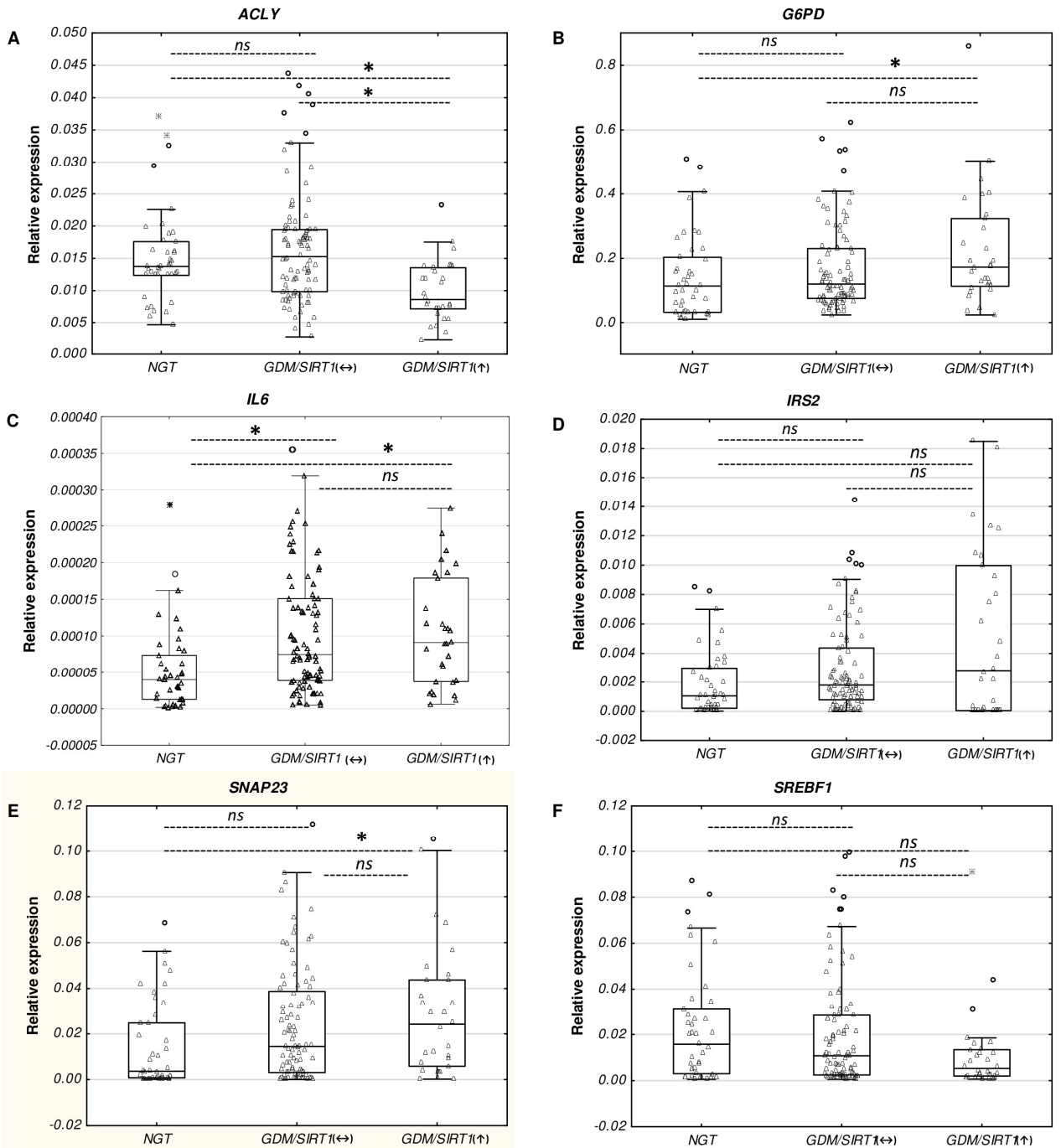

Figure 2. Verification results of the genes ACLY (A), G6PD (B), IL6 (C), IRS2 (D), SNAP23 (E), and SREBF1 $(\mathbf{F})$ in NGT $(n=41), \operatorname{GDM} / \operatorname{SIRT1}(\leftrightarrow)(n=92)$, and GDM/SIRT1( $\uparrow)(n=30)$ groups by RT-qPCR. All mRNA levels of the investigated genes were normalized to a mean of the endogenous control GAPDH. Data are expressed as median \pm interquartile range $(25-75 \%) ;{ }^{*} p<0.05$, as assessed by post hoc test for pairwise multiple comparisons of mean rank sums; n.s.: non-significant. 


\subsection{Functional analysis using Ingenuity Pathway Analysis (IPA)}

To further determine the biological significance and functional classification of the genes whose expression was statistically different in the GDM/SIRT1(个) group (i.e., SIRT1, ACLY, G6PD, IL6, and SNAP23, $p<0.05)$, IPA analysis was performed. The most significant disorders of biological functions associated with these genes were found to be inflammatory response, cardiovascular disease, organismal injury and abnormalities, immunological disease, and inflammatory disease (Table 6). Cell-to cell signaling and interaction, cellular development, drug metabolism, molecular transport, and small molecule biochemistry were the most significant molecular and cellular functional categories. Hematological system development and function, immune cell trafficking, cardiovascular system development and function, organ morphology, and organismal development were the most significant categories in physiological development and system function (Table 6). The dominant canonical pathways included the Sirtuin signaling pathway, acetyl-CoA biosynthesis III (from citrate), the pentose phosphate pathway, and differential regulation of cytokine production in macrophage and Thelper cells by IL17A and IL17F (Table 7). As shown in Figure 3, there was only one significant gene network involved in cell-to-cell signaling and interaction, hematological system development and function, inflammatory response (score 12) found in the GDM/SIRT1( $\uparrow$ ) patients.

Table 6. Biological function associated with GDM/SIRT1( $\uparrow)$ identified based on Ingenuity Pathway Analysis (IPA).

\begin{tabular}{|c|c|c|c|}
\hline Category & Top Function & $p$ Range & Number of Targets \\
\hline \multicolumn{4}{|l|}{ Disease and disorder } \\
\hline 1 & Inflammatory response & $6.60 \times 10^{-6}-3.24 \times 10^{-2}$ & 3 \\
\hline 2 & Cardiovascular disease & $2.54 \times 10^{-5}-4.55 \times 10^{-2}$ & 3 \\
\hline 4 & Immunological disease & $9.57 \times 10^{-5}-2.33 \times 10^{-2}$ & 2 \\
\hline 5 & Inflammatory disease & $9.57 \times 10^{-5}-1.53 \times 10^{-2}$ & 2 \\
\hline \multicolumn{4}{|c|}{ Molecular and cellular function } \\
\hline 3 & Drug metabolism & $3.82 \times 10^{-5}-1.41 \times 10^{-2}$ & 2 \\
\hline 4 & Molecular transport & $3.82 \times 10^{-5}-3.04 \times 10^{-2}$ & 5 \\
\hline 5 & Small molecule biochemistry & $3.82 \times 10^{-5}-3.04 \times 10^{-2}$ & 4 \\
\hline \multicolumn{4}{|c|}{$\begin{array}{l}\text { Physiological system } \\
\text { development and function }\end{array}$} \\
\hline 1 & Hematological system development and function & $6.60 \times 10^{-6}-4.82 \times 10^{-2}$ & 4 \\
\hline
\end{tabular}

This selection is organized by the negative logarithm of $p$-values (Fisher test), calculated by IPA ([-Log $(0.05)=1.3])$. The $p$-value range indicates the $p$-values of the various pathways and processes belonging to that category. The number of targets indicates the total number of genes associated with the functional category.

Table 7. List of top five most significant canonical pathways.

\begin{tabular}{|c|c|}
\hline Pathways & $p$ \\
\hline Sirtuin signaling pathway & $4.20 \times 10^{-5}$ \\
\hline Acetyl-CoA biosynthesis III (from citrate) & $3.01 \times 10^{-4}$ \\
\hline Pentose phosphate pathway (oxidative branch) & $1.20 \times 10^{-3}$ \\
\hline Pentose phosphate pathway & $3.01 \times 10^{-3}$ \\
\hline Differential regulation of cytokine production in macrophage and T helper cells by IL-17A and IL-17F & $5.41 \times 10^{-3}$ \\
\hline
\end{tabular}




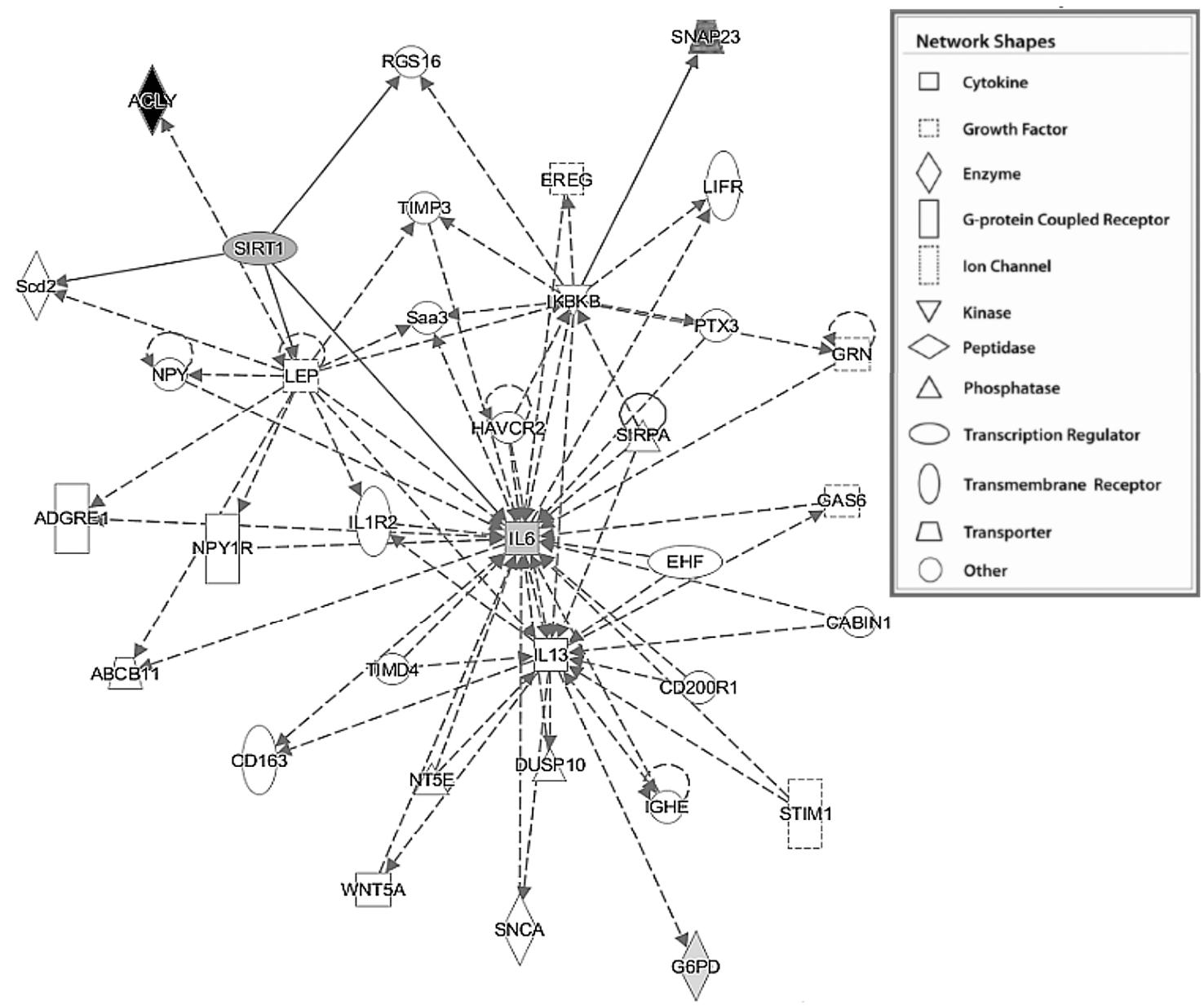

Figure 3. Cell-to cell signaling and interaction, hematological system development and function, inflammatory response network in the GDM/SIRT1( $\uparrow)$ patients, as identified by IPA. The five genes (SIRT1, ACLY, G6PD, IL6, and SNAP23) verified as significant in the entire GDM/SIRT1( $\uparrow$ ) group $(p<0.05)$ were converted into a gene network by IPA software. The figure displays the network graphically as nodes (gene/gene product) and edges (biological relationship between nodes). The up-regulated genes are shown in gray shading, with the color intensity indicating the fold change in expression, whereas the down-regulated gene (ACLY) is shown in black. A direct relationship is presented as a straight line, and an indirect relationship as a dotted line. Genes involved in the network that are not included in the transcriptome results are shown in white. The node shapes are indicative of function, with the legend given to the right.

\section{Discussion}

GDM is a chronic, multifactorial, and complex disease involving transcriptional dysregulation in multiple tissues and organs, including leukocytes. As SIRT1 regulates a wide spectrum of important cellular processes, it is clear that changes in its expression may disturb many vital functions in the human body. Although a considerable body of evidence exists indicating that SIRT1 may play a role in T2DM, there is actually no consensus as to whether it is relevant to GDM. To clarify this issue, this unique and multistage study systematically examines the molecular changes associated with SIRT1 overexpression in leukocytes from a group of clinically well-characterized diabetic pregnancies displaying homogeneous leukocyte SIRT1 expression (i.e., the GDM/SIRT1( $\uparrow$ ) group) at the time of GDM diagnosis.

In the first stage of the study, the leukocyte SIRT1 mRNA level was found to be significantly higher in the entire GDM $(n=122)$ than the NGT $(n=41)$ groups, which also correlated with glucose metabolism; this relationship suggests that a close link may exist between leukocyte 
SIRT1 expression and glucose homeostasis. This finding was unexpected, especially in view of previous data showing decreased SIRT1 expression or activity in patients with T2DM or metabolic syndrome $[13,28]$. Although the reason for this discrepancy is unclear, it may be due to the fact that previous studies were based on a different cell type: peripheral blood mononuclear cells (PBMC) were used by de Kreutzenberg, while whole leukocytes were used in the present study [13]. Significantly higher SIRT1 mRNA expression has been reported in granulocytes compared with lymphocytes and monocytes [29]. Alternatively, the differences may be attributed to patient characteristics: firstly, the patients enrolled in the present study were younger (30.5 (27.0-33.0) years) than those included in previous studies ( $48.0 \pm 1.5$ years and $62.01 \pm 8.67$ years) and secondly, while the GDM and NGT groups in the present study demonstrated similar parameters of adiposity (i.e., pre-and pregnancy BMI, body weight gain) and insulin resistance (i.e., insulin level and HOMA-IR), the insulin resistant subjects in the de Kreutzenberg study [13] and the Song study [28] presented increased BMI. Nevertheless, our findings are in line with those of a more recent study revealing increased SIRT1 expression at one day postpartum in GDM women as a consequence of their exposure to hyperglycemia during GDM [25]. Hence, our results suggest that increased leukocyte SIRT1 mRNA expression plays a role in diabetic pregnancy; they also enrich the current understanding of the field of GDM biology, in that SIRT1 overexpression appears to be important not only during the postpartum period following pregnancy complicated by GDM, but also at the time of GDM diagnosis itself. Low to moderate (2.5- to 7.5-fold) cardiac-specific Sirt1 overexpression in transgenic mice has been demonstrated to protect cardiomyocytes from apoptosis and age-dependent degeneration, whereas its greater increase (12.5-fold) has a detrimental effect on these cells, leading to cardiomyopathy [30].

SIRT1 expression has been found to generally decrease with age and obesity [31,32]. However, since maternal age and adiposity were comparable between women with and without GDM in the present study, and furthermore, since leukocyte SIRT1 expression remained significantly increased in the GDM group, even after adjustment for these potentially relevant variables, we may exclude their possible effect on leukocyte SIRT1 up-regulation in GDM women.

Although calorie restriction (CR) has been proven to extend the lifespan in lower organisms and mammals through its effect on sirtuins, as evidenced by increased SIRT1 expression in the adipose tissue, liver, kidney, and brain tissue of rodents, as well as in PBMC [33-35], it has also been found that the plasma SIRT1 concentration falls in pregnant women during Ramadan fasting to a degree that correlates inversely with the number of fasting days [36]. Physical activity has also been documented as a positive regulator of SIRT1 expression in rats and humans [37,38]. Unfortunately, as no information was available on diet and excise interventions among the pregnancies enrolled in our study, it was not possible to consider their impact on leukocyte SIRT1 expression in GDM patients. In addition, the 12-h overnight fast undertaken by the study participants before blood sampling in the present study appears to be too short to increase the SIRT1 mRNA level in their leukocytes [13,39].

To further clarify the metabolic and transcriptional rearrangements associated with leukocyte SIRT1 overexpression during GDM, a stratified expression analysis of leukocyte SIRT1 status was performed in the GDM patients, which allowed a GDM/SIRT1 $\uparrow \uparrow(n=30)$ group to be discriminated from a GDM/SIRT1 $\leftrightarrow)(n=92)$ group. Such molecular stratification of patients is a practical approach for better interpretation of experimental results and more effective characterization of the disease in cases when large diversity is present in the gene expression data obtained from clinical samples. Compared to the NGT group, the two GDM groups exhibited significantly higher fasting and post-load glucose concentrations, which, along with the plasma $\mathrm{HbA1c}$ level, positively correlated with leukocyte SIRT1 expression; this implies a linkage between leukocyte SIRT1 mRNA up-regulation and both the early and late phase of hyperglycemia. Of note, the glycemic measurements were increased in the GDM/SIRT1( $\uparrow$ ) group compared to the GDM/SIRT1( $\leftrightarrow)$ group, but this difference was not statistically significant.

As the complex molecular events related with SIRT1 overexpression in leukocytes of GDM patients were unknown, the study also compared the changes in leukocyte-induced expression of 
diabetes-related genes taking place in hyperglycemic GDM/SIRT1( $\uparrow$ ) women with those in the NGT controls using RT-qPCR array technology. Such an approach has previously led to the successful identification of key factors involved in T2DM development [40]. The present study used the pooled RNA samples of the GDM/SIRT1( $\uparrow)(n=9)$ and the NGT $(n=7)$ patients to eliminate donor-donor variation and to obtain results reflecting consistent SIRT1-related transcriptomic changes in diabetes-related genes: a strategy previously described in other studies [41,42]. The current study identified an 11-gene signature that accurately distinguished the GDM/SIRT1( $\uparrow$ ) group from the NGT group based on at least a two-fold difference in expression, with four genes up-regulated and seven down-regulated in the GDM group compared to the NGT group. These were assigned to five different functional clusters, including metabolic enzymes ( $A C L Y, G 6 P D, G P D 1)$, molecular transport functions (NSF, SNAP23, STXBP2), transcription factors (PDX1 and SREBF1), signal transduction molecules (IRS1 and IRS2), and an inflammatory factor (IL6). Thus, leukocyte SIRT1 overexpression in the GDM/SIRT1( $\uparrow)$ patients is closely related to transcriptional changes in genes involved with a diverse set of biological functions, and the importance of several of them has been attributed to GDM-related functions $[43,44]$.

Since quantitative and qualitative differences were seen in the transcriptional expression pattern of leukocytes between the pooled RNA samples of GDM/SIRT1( $\uparrow)$ and NGT women, the next stage more closely examined the PCR array data in the entire experimental groups of GDM/SIRT1( $\uparrow)(n=30)$ versus NGT $(n=41)$. Of the 11 genes, six were selected which represented each of the five functional clusters: SNAP23, ACLY, G6PD, IL6, IRS2, and SREBF1. Comparative expression analysis of all these genes revealed significantly higher levels of G6PD (FC = 1.52), IL6 (FC = 2.28), and SNAP23 (FC = 6.55) transcripts and a lower level of the $A C L Y$ transcript (FC $=0.63$ ) in the GDM/SIRT1( $\uparrow$ ) group compared to the NGT group, whereas no significant differences were found between the groups with regard to IRS2 (FC = 2.62) and SREBF1 (FC = 0.34) expression. Nevertheless, the expression of all analyzed genes among the GDM/SIRT1( $\uparrow$ ) group was regulated in the same direction as on the PCR array, confirming the reliability of the results obtained, irrespective of the RNAs used (pooled versus non-pooled) and different primer sets employed in the two methods. When the expression of the aforementioned genes was further analyzed between the GDM/SIRT1 $(\leftrightarrow)$ and NGT groups, only the expression of IL6 (FC = 1.88) was significantly higher in the diabetic pregnancies; this suggests it is linked to GDM, regardless of the mRNA expression status of SIRT1 in GDM patients.

IL6 is a pleiotropic cytokine that has been implicated not only in inflammation, but also in glucose metabolism, and its concentration in GDM patients has been found to be elevated, independent of BMI [45]. Although controversy still exists whether hyperglycemia is a cause or an effect of increased IL6 expression [46-48], it is reasonable to assume that our finding of an increased leukocyte IL6 expression in both groups of GDM patients may be associated with their hyperglycemic state. It is also possible that hyperglycemia-induced oxidative stress could participate in this event, since sugar-derived substances called advanced glycation end products (AGEs) have been reported to stimulate IL6 production in human monocytes [49]. Unfortunately, this study did not examine the oxidative stress markers that could fully confirm this hypothesis; further studies are clearly needed in this field since hyperglycemia-induced oxidative stress is an important contributor to GDM development, with health consequences for both mother and fetus [50].

Among the significantly up-regulated genes identified in the GDM/SIRT1( $\uparrow$ ) patients, SNAP23 was the most increased. The gene encodes synaptosomal-associated protein 23, a soluble $\mathrm{N}$-ethyl-maleimide-sensitive fusion protein attachment protein receptor (SNARE) molecule, which is engaged in transport vesicle docking and fusion. Despite evidence indicating that a deficiency in several SNARE proteins is linked to T2DM development, and an increase of their cellular levels may lead to the maintenance of glucose homeostasis, the precise role of SNARE members in intracellular trafficking during diabetes is far from being well-understood [51]. Interestingly, a recent study by Rezaei Farimani et al. [52] reported that resveratrol increases SNAP23 gene expression in diabetic animals; it is hence theoretically possible that the increased leukocyte SNAP23 expression in the 
GDM/SIRT1( $\uparrow$ ) group observed in our study could be an adaptive response to SIRT1 overexpression in diabetic pregnancies. However, this remains speculative until specifically addressed in future studies.

Another gene of interest that showed a significant increase in expression in the GDM/SIRT1( $\uparrow)$ group was G6PD, encoding glucose-6-phosphate dehydrogenase (G6PD): the rate-limiting enzyme in the pentose-phosphate pathway that catalyzes the dehydrogenation reaction of glucose-6-phosphate to 6-phosphogluconolactone and reduces nicotinamide adenine dinucleotide phosphate (NADPH). NADPH is required not only for fatty acid and cholesterol biosynthesis, but also for the regeneration of reduced forms of the two important antioxidants, such as glutathione and thioredoxin. Hence, G6PD displays a cytoprotective action against oxidative stress, i.e., a key pathological factor associated with diabetes. Accumulating data indicates decreased G6PD activity related with oxidative damage, cellular dysfunction, and organ damage in endothelial cells, kidney, liver, and red blood cells under high glucose conditions [53-55]. On the other hand, increased G6PD activity has been shown to improve redox status and cell growth, and decrease cell death in endothelial cells [56]. Several studies also point to a potential link between G6PD deficiency and the development of diabetes, including GDM $[57,58]$. Recently, resveratrol has been found to improve G6PD activity in an animal model of diabetes [59]. These findings raise the possibility that the up-regulation of leukocyte G6PD observed in the GDM/SIRT1(个) patients in the present study might be the adaptive mechanism to leukocyte SIRT1 overexpression which would protect diabetic pregnancies against oxidative stress and cellular dysfunction. Of course, further studies are required to clarify whether leukocyte SIRT1 and G6PD up-regulation might mediate antioxidative effects during gestational diabetes.

Out of the set of genes whose expression was found to be significantly changed in the GDM/SIRT1( $\uparrow$ ) group, only ACLY was down-regulated. This gene encodes a cytoplasmic adenosine triphosphate (ATP) citrate lyase (ACL) that converts citrate to acetyl-coenzyme A (CoA), a key compound for de novo lipid synthesis. Hence, ACL is currently considered as a potential therapeutic target for lipid reduction in obesity and obesity-related metabolic diseases [60,61]. In addition, several observations support the notion that ACL is crucial for histone acetylation and the control of DNA accessibility for gene transcription [62]. In this regard, increased histone acetylation via the citrate lyase pathway has been shown in cultured mammalian cells under hyperglycemic conditions [63]. More speculatively, it seems logical that the leukocyte $A C L Y$ down-regulation observed in the GDM/SIRT1( $\uparrow)$ group in the present study might lead to impaired de novo lipogenesis; in addition, the GDM/SIRT1( $\uparrow$ ) pregnancies also demonstrated lower leukocyte SREBF1 expression than the NGT controls, although this change was not significant. The gene SREBF1 encodes sterol regulatory element binding protein 1 , which is a well-known transcriptional factor participating in the regulation of lipid metabolism by promoting the expression of numerous lipogenic genes, including ACLY [64]. On the other hand, it cannot be excluded that $A C L Y$ down-regulation might serve as the adaptive change to leukocyte SIRT1 overexpression taking place in the GDM group, since SIRT1, acting as histone deacetylase, might diminish histone acetylation by inactivating histone acetyltransferase activity. Hence, it will be of great importance to investigate whether specific genes might be altered in leukocytes with increased SIRT1 expression as a result of ACL inhibition. It is noteworthy that the GDM/SIRT1( $\uparrow)$ and GDM/SIRT1 $(\leftrightarrow)$ groups differed with regard to the directionality of leukocyte $A C L Y$ expression; as it was previously mentioned, the leukocyte ACLY mRNA level was significantly down-regulated in the GDM/SIRT1( $\uparrow)$ patients compared to both the NGT and GDM/SIRT1( $\leftrightarrow)$ groups and non-significantly up-regulated in the GDM/SIRT1( $\leftrightarrow$ ) subjects compared to NGT controls, indicating that the effect of $A C L Y$ expression may be distinct in leukocytes, depending on the SIRT1 expression status in these cells. Hence, leukocyte ACLY down-regulation in the GDM/SIRT1( $\uparrow)$ pregnancies at the time of GDM diagnosis appears to be specific in these subjects, making this gene potentially relevant for their metabolic responses.

In addition to identifying the individual genes linked to SIRT1 overexpression, the study also analyzed the biological functions and networks in which the set of four significantly changed genes (ACLY, G6PD, IL6, SNAP23), along with SIRT1, may play critical roles. IPA was used to identify 
significant canonical pathways in leukocytes, including the Sirtuin signaling pathway, acetyl-CoA biosynthesis III (from citrate), and the pentose phosphate pathway; in addition, differential regulation of cytokine production was also identified in macrophage and T helper cells by IL17A and IL17F. According to the above described biological functions of the altered genes, their involvement in the first three pathways is not surprising. The latter pathway is involved in pathogenic events taking place during inflammatory diseases, since a pro-inflammatory cytokine IL17A has been shown to regulate NF-kappa B and mitogen-activated protein kinases (MAPK) and induces the expression of IL6 and cyclooxygenase 2 (COX2) [65,66]. A recent study of IL17 revealed that SIRT1 plays a protective role in proliferative diabetic retinopathy by suppressing IL17 production [67]. Among the most relevant biological functions of the aforementioned genes were inflammatory response, cardiovascular disease, cell-to cell signaling and interaction, cellular development, hematological system development and function, and immune cell trafficking, confirming their effect on changes in cellular and immunological functions in GDM $[68,69]$. Our analysis strategy also revealed the top biological gene interaction network containing the greatest number of differentially-expressed genes involved in cell-to-cell signaling and interaction, hematological system development and function, and the inflammatory response, thus highlighting the functional and biological importance of the set of selected genes in GDM.

The present study design has several limitations. First, it did not assess the expression of both SIRT1 and selected genes at the protein level among all study participants. Therefore, further proteomics studies are needed to determine whether the identified changes in gene expression truly reflect the changes in their protein amounts or activities. Such investigations are currently under way in our research group. A second limitation is that mRNA from whole leukocytes was used; hence, the leukocyte transcriptional alterations observed in our study cannot reflect cell-type specific changes in the leukocyte subpopulations. However, our intent was to examine the overall response of leukocytes to metabolic changes occurring in GDM. A final limitation is the lack of PCR array results for the GDM/SIRT1( $\leftrightarrow$ ) subjects; however, as transcriptional differences in most diabetes-related genes were found to be modest between the GDM/SIRT1( $\uparrow$ ) and NGT groups, it may be expected that they will be smaller between the GDM/SIRT1 $\leftrightarrow$ ) and NGT groups. Therefore, our research strategy was based on the identification of genes with differential expression (2-fold or more) by PCR array expression profiling of leukocytes from the small number of GDM/SIRT1( $\uparrow$ ) patients, followed by verification of their expression in a relatively large number of diabetic patients of the GDM/SIRT1( $\uparrow)$ and GDM/SIRT1 $(\leftrightarrow)$ groups, thus improving the accuracy and reliability of our results.

\section{Materials and Methods}

\subsection{Study Population}

A total of 163 pregnant Caucasian women (41 with NGT and 122 with GDM) were enrolled and studied at the Outpatient Diabetological Clinic "OmniMed" in Lodz, Poland. All pregnant women underwent a $75 \mathrm{~g}$ oral glucose tolerance test (OGTT) at 24-28 weeks' gestation, or later if it was not possible during this period. GDM was diagnosed according to the Polish Diabetes Association (PDA) 2011 guidelines (modified WHO diagnostic criteria) [70], with the following threshold glucose levels: fasting $\geq 100 \mathrm{mg} / \mathrm{dL}(5.6 \mathrm{mmol} / \mathrm{L}), 1 \mathrm{~h} \geq 180 \mathrm{mg} / \mathrm{dL}(10.0 \mathrm{mmol} / \mathrm{L})$, or $2 \mathrm{~h} \geq 140 \mathrm{mg} / \mathrm{dL}(7.8 \mathrm{mmol} / \mathrm{L})$ (PDA 2011). The pregnant NGT women had a negative screen.

All patients were eligible to participate unless they had one or more exclusion criteria: age $<18$ and $>40$ years, family history of diabetes in first-degree relatives, GDM in previous pregnancy, the occurrence of any form of pre-pregnancy diabetes, the presence of concomitant systemic disease (chronic or acute or infectious), and taking insulin or any oral hypoglycemic medications. Neither GDM nor NGT subjects were controlled in terms of diet and exercise before the overnight fast. 
All clinical investigations were conducted in accordance with the guidelines of The Declaration of Helsinki, and approved by the Ethical Committee of the Medical University of Lodz (No. RNN/153/09/KB, 21 April 2009). All patients gave informed consent before joining the study.

\subsection{Anthropometric and Biochemical Data}

Data concerning maternal age and pre-pregnancy weight were provided by participants. Pregnancy height and weight were measured at the OGTT visit using standardized procedures and calibrated equipment. Body mass index (BMI) was calculated by dividing the weight in kilograms by the height in meters squared.

Blood samples were collected from the patients after a 12-h overnight fast. Biochemical assays for determining blood glucose, insulin, glycated hemoglobin (HbA1c), C-reactive protein (CRP), and lipid profile, i.e., total cholesterol (TC), triglycerides (TGs), and high-density lipoprotein (HDL)and low-density lipoprotein (LDL)-cholesterol, were performed with standard laboratory methods as previously described [71,72].

Plasma glucose and insulin values were used to calculate a homeostasis model assessment of insulin resistance (HOMA-IR) as follows [73]:

HOMA-IR $=[$ fasting insulin $(\mu \mathrm{U} / \mathrm{mL}) \times$ fasting glucose $(\mathrm{mg} / \mathrm{dL}) / 405$.

\subsection{Leukocytes Separation}

Blood $(10 \mathrm{~mL})$ was collected from patients in EDTA-containing tubes. Leukocytes were isolated immediately after blood draws as previously described [71]. Briefly, patient blood samples were spun down at $3000 \mathrm{rpm}$ for $10 \mathrm{~min}$ at $4{ }^{\circ} \mathrm{C}$ and the plasma supernatant was discarded. After adding red blood cell lysis buffer ( $0.5 \mathrm{M} \mathrm{NH}_{4} \mathrm{Cl}, 10 \mathrm{mM} \mathrm{KHCO}_{3}, 10 \mathrm{mM}$ EDTA, $\left.\mathrm{pH} 8.0\right)$ and 30 min incubation on ice, the samples were centrifuged at $4000 \mathrm{rpm}$ for $10 \mathrm{~min}$ at $4{ }^{\circ} \mathrm{C}$. The pellets containing leukocytes were washed twice with the phosphate-buffered saline (PBS).

\subsection{RNA extraction and SIRT1 Gene Expression Assay}

Total RNA was extracted from leukocytes using commercially-available acid-phenol reagent (Tri Reagent, Sigma-Aldrich, St. Louis, MO, US), according to the manufacturer's instruction, and its quantity and quality were assessed with a LAMBDA 25 UV spectrophotometer (PerkinElmer, Chorley, UK) at UV260 and UV260/280, respectively. RNA (1 $\mu \mathrm{g})$ was converted to cDNA using the RevertAid ${ }^{\mathrm{TM}}$ First Strand cDNA Synthesis Kits (Fermentas, Vilnius, Lithuania), according to the manufacturer's instructions.

Leukocyte SIRT1 gene expression was determined in the GDM $(n=122)$ and NGT $(n=41)$ groups by semi-quantitative PCR carried out in a TPersonal 48 Thermocycler (Biometra, Göttingen, Germany) using a reaction mix containing cDNA $(1 \mu \mathrm{L})$, Taq DNA polymerase $(0.6$ unit), dNTPs $(200 \mu \mathrm{M})$, $10 \times$ reaction buffer, and forward and reverse primers $(1 \mu \mathrm{M})$ for SIRT1, with the sequences depicted in Table 8. The leukocyte SIRT1 expression level was normalized to the housekeeping gene GAPDH, encoding the glyceraldehyde 3-phosphate dehydrogenase, since its expression was stable between sample groups. After an initial denaturation at $95{ }^{\circ} \mathrm{C}$ for three minutes, amplification was performed with denaturation at $95^{\circ} \mathrm{C}$ for $25 \mathrm{~s}$, annealing at $56^{\circ} \mathrm{C}$ for $30 \mathrm{~s}$, and extension at $72{ }^{\circ} \mathrm{C}$ for $30 \mathrm{~s}$ for 27 cycles, followed by at $72{ }^{\circ} \mathrm{C}$ for $10 \mathrm{~min}$. Each PCR reaction was run in duplicate. The amplification products (544-bp and 514-bp for SIRT1 and GAPDH, respectively) were analyzed on 1.2\% agarose gels stained with ethidium bromide and quantified by densitometry with the Gelix One 220 program (Biostep $\mathrm{GmbH}$, Jahnsdorf, Germany).

Due to the high degree of heterogeneity in leukocyte SIRT1 expression among the entire GDM group, the GDM patients were subsequently stratified into two subgroups: (i) a GDM/SIRT1( $\uparrow$ ) group consisting of GDM patients $(n=30)$ who exhibited significantly increased leukocyte SIRT1 expression compared to the NGT group ( $p<0.05$ ); and (ii) a GDM/SIRT1 $(\leftrightarrow)$ group consisting of GDM patients $(n=92)$ who exhibited unchanged leukocyte SIRT1 expression compared to the NGT group 
$(p>0.05)$. The threshold limit for GDM group separation was demarcated experimentally to reach the following criteria: (i) the lack of significant differences in leukocyte SIRT1 expression between the GDM/SIRT1 $(\leftrightarrow)$ and NGT groups; (ii) the occurrence of a significant difference in leukocyte SIRT1 expression between the GDM/SIRT1( $\uparrow$ ) and NGT groups; and (iii) the similarity of leukocyte SIRT1 expression among the NGT and GDM/SIRT1 $\leftrightarrow$ ) groups. In order to establish the threshold limit value for GDM group stratification into the GDM/SIRT1( $\leftrightarrow)$ and GDM/SIRT1( $\uparrow)$ subgroups, the $2 \Delta \mathrm{C}(\mathrm{T})$ value of 1.413 (the upper quartile equals to the 75 th percentile of the data) was calculated.

\subsection{Human Diabetes $R T^{2}$ Profiler ${ }^{\mathrm{TM}}$ PCR Array}

The relative expression of diabetes-related genes was determined in leukocytes of the selected GDM patients $(n=9)$ with the highest SIRT1 expression among the GDM group, namely GDM/SIRT1( $\uparrow)$, versus NGT controls $(n=7)$ by using a 96-well RT2 Profiler ${ }^{\mathrm{TM} P C R}$ Array. (PAHS-023Z-Human Diabetes PCR Array, SA BiosciencesTM, A Qiagen Company, USA) This profiles the expression of 84 genes involved in the development and progression of diabetes, as well as five housekeeping genes (beta-2-microglobulin, B2M); hypoxanthine phosphoribosyltransferase 1, HPRT1; ribosomal protein L13a, RPL13A; GAPDH; actin beta, ACTB) by real-time PCR using the SYBR Green detection method. It also contains controls for genomic DNA contamination, RNA quality, and general PCR performance. The 84 genes investigated were grouped into six functional categories based on the Qiagen listing as follows: (i) receptors, transporters, and channels; (ii) nuclear receptors; (iii) metabolic enzymes; (iv) secreted factors; (v) signal transduction molecules; and (vi) transcription factors (Table S1).

Equal amounts of total RNA from samples taken from nine GDM/SIRT1( $\uparrow)$ patients were pooled together $(1 \mu \mathrm{g})$, and then reverse transcribed to form cDNA using the RT2 First Strand Kit (C-03/330401, SA Biosciences ${ }^{\mathrm{TM}}$, A QIAGEN Company, Venlo, The Netherlands), as described by the manufacturer. The same procedure was applied for seven NGT controls. The expression of the 84 diabetes-related genes was then evaluated by diluting the samples in RT2 Real-Time ${ }^{\text {TM }}$ SYBR Green PCR master mix according to the supplier's directions, which were then pipetted into 96-well PCR array plates. Real-time PCR was performed in technical duplicates using the 7900HT Fast Real-Time PCR System (Applied Biosystems, Foster City, CA, USA). PCR reaction conditions were as follows: $95^{\circ} \mathrm{C}$ for $10 \mathrm{~min}$ followed by 40 cycles of $95^{\circ} \mathrm{C}$ for $15 \mathrm{~s}$, and $60^{\circ} \mathrm{C}$ for $1 \mathrm{~min}$. Quality controls included within the array plates confirmed a lack of DNA contamination, and that RNA quality and PCR performance were acceptable.

Raw data obtained from the real-time PCR was analyzed using an MS-Excel sheet from the manufacturer's website (http: / / www.sabiosciences.com/pcrarraydataanalysis.php), and the threshold cycle $(\mathrm{Ct})$ cutoff was set at 35 cycles. For these calculations, the mean expression of the five reference genes was used, since it did not differ between the GDM and NGT groups. Fold changes (FC) in average gene expression were expressed as the difference in expression of the individual diabetes-related gene from the GDM/SIRT1( $\uparrow$ ) group compared to those of the NGT group. Genes were considered to be up-regulated or down-regulated if changes in expression levels were $\geq 2$-fold or $\leq 2$-fold, respectively.

\subsection{Quantitative RT-PCR Verification}

To verify the findings of gene transcript measurements performed on the pooled RNA samples of the patients, RT-qPCR analysis was performed for the same six selected genes with altered expression (i.e., ACLY, G6PD, IL6, IRS2, SNAP23 and SREBF1) in each of the RNA samples obtained from leukocytes of individuals belonging to the GDM/SIRT1( $\uparrow)(n=30), \operatorname{GDM} / \operatorname{SIRT1}(\leftrightarrow)(n=92)$, and NGT $(n=41)$ groups. For this purpose, total RNA was isolated from leukocytes of each

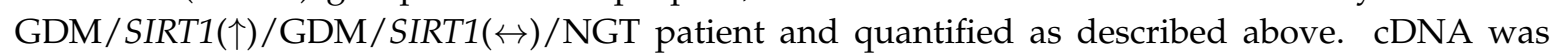
synthesized from $1 \mu \mathrm{g}$ total RNA using the RevertAid ${ }^{\mathrm{TM}}$ First Strand cDNA Synthesis Kits (Fermentas, Vilnius, Lithuania), according to the manufacturer's recommendations. PCR reactions were carried out in duplicate with cDNA template diluted 1:10 and MaximaTM SYBR Green/ROX qPCR Master 
Mix $(2 \times)$ (Thermo Fisher Scientific, Waltham, MA, USA) using the 7500 Real Time PCR System (Applied Biosystems, Foster City, CA, USA). For each gene analyzed, a specific pair of primers was designed using the online Primer 3 program (www.fokker.wi.mit.edu/primer3/input.htm). The primer sequences are listed in Table 8. The amplification conditions started with initial denaturation at $95^{\circ} \mathrm{C}$ for $10 \mathrm{~min}$, followed by 40 cycles of $95^{\circ} \mathrm{C}$ for $1 \mathrm{~min}$ and $60^{\circ} \mathrm{C}$ for $1 \mathrm{~min}$. The specificity of the product was assessed from the melting curve analysis. Average gene $\mathrm{Ct}$ values were normalized to the average GAPDH values of the same cDNA sample. Of note, the choice of experimental method did not appear to have any effect on GAPDH gene expression. No amplification was observed for RNA not subjected to reverse transcriptase during CDNA synthesis or in PCR reactions using water instead of a template. Gene expression levels were determined using the comparative $\mathrm{Ct}$ method.

Table 8. Primer sequences used for PCR reactions.

\begin{tabular}{|c|c|c|}
\hline Gene Symbol & Primer Sequence $5^{\prime} \rightarrow 3^{\prime}$ & $\begin{array}{c}\text { Amplicon Size } \\
\text { (bp) }\end{array}$ \\
\hline \multicolumn{3}{|l|}{ Semi-quantitative PCR } \\
\hline SIRT1 & $\begin{array}{l}\text { F: TCACCACCAGATTCTTCAGTG } \\
\text { R: CCTCTTGATCATCTCCATCAGTC }\end{array}$ & 544 \\
\hline GAPDH & $\begin{array}{l}\text { F: CTGCACCACCAACTGCTTAG } \\
\text { R: GTTGCTGTAGCCAAATTCGTTG }\end{array}$ & 514 \\
\hline \multicolumn{3}{|c|}{ (2) } \\
\hline ACLY & $\begin{array}{l}\text { F: TCTTTGTGCTGGGAAGGAGT } \\
\text { R: GTAGGGTGCCTACTGCTATG }\end{array}$ & 90 \\
\hline$G 6 P D$ & $\begin{array}{l}\text { F: ACGTCCGTGATGAGAAGGTC } \\
\text { R: GTGGGGTCGTCCAGGTAC }\end{array}$ & 133 \\
\hline IL6 & $\begin{array}{l}\text { F: CCTGAGAAAGGAGACATGTAACAAG } \\
\text { R: AAGGTTCAGGTTGGTTTTCTGCC }\end{array}$ & 79 \\
\hline IRS2 & $\begin{array}{l}\text { F: CGGTGAGTTCTACGGGTACAT } \\
\text { R: TCAGGGTGTATTCATCCAGCG }\end{array}$ & 194 \\
\hline SNAP23 & $\begin{array}{l}\text { F: TAGCCATTGAGTCTCAGGATG } \\
\text { R: GGTTTAGTTGTTCCTTTTGTTCA }\end{array}$ & 72 \\
\hline SREBF1 & $\begin{array}{l}\text { F: ACAGTGACTTCCCTGGCCTAT } \\
\text { R: GCATGGACGGGTACATCTTCAA }\end{array}$ & 222 \\
\hline GAPDH & $\begin{array}{l}\text { F: GGTGGTCTCCTCTGACTTCAACA } \\
\text { R: GTTGCTGTAGCCAAATTCGTTGT }\end{array}$ & 27 \\
\hline
\end{tabular}

\subsection{Bioinformatics Analysis}

To identify the statistically-significant biological functions and signaling pathways associated with differentially-expressed genes in leukocytes of the GDM/SIRT1( $\uparrow$ ) pregnancies (i.e., SIRT1, ACLY, G6PD, IL6, and SNAP23, $p<0.05$ ), Ingenuity Pathways Analysis was performed (IPA; Ingenuity $\mathrm{H}$ Systems, Redwood City, CA, USA; http:/ / www.ingenuity.com). For this purpose, expression values of these genes obtained from RT-qPCR verification analysis were uploaded into the IPA Tool system. The core analysis was overlaid with the global molecular network in the Ingenuity Pathway Knowledge Base (IPKB) and highly interconnected gene networks and pathways were constructed. The significance of the associations between the data set and gene networks and canonical pathways was determined by a $p$ value calculated using the Fisher's exact test. $p \leq 0.05$ was considered statistically significant.

\subsection{Statistical Analysis}

Data are presented as medians with interquartile ranges (25-75th percentile). The distribution of the analyzed biochemical and expression data was checked by the Shapiro-Wilk test. Differences of non-normally distributed variables between two groups were assessed using the non-parametric Mann-Whitney U (Wilcoxon's) test. The Spearman's rank correlation coefficients were calculated to 
evaluate univariate correlations between leukocyte SIRT1 gene expression and clinical parameters of patients. Differences of each variable between three groups (i.e., NGT, GDM $/ \operatorname{SIRT1}(\leftrightarrow)$, and GDM/SIRT1( $\uparrow)$ groups) were compared using the Kruskal-Wallis test. The pairwise post hoc test for multiple comparisons of mean rank of sums was employed to determine which specific groups differed from each other [74]. To evaluate leukocyte SIRT1 expression between the GDM and NGT groups with adjustment for age and obesity variables (pre- and pregnancy BMI and gestational weight gain), ANCOVA analysis was performed. $p$ value $\leq 0.05$ was considered significant. Statistical analyses were performed using commercially-available statistics analysis software (Statistica version 8.0, StatSoft, Poland, license AXAP911E504325AR-K).

\section{Conclusions}

In this study, an integrative approach combining PCR technology with bioinformatics was used to elucidate genetic factors associated with leukocyte SIRT1 overexpression in GDM. To the best of our knowledge, this is the first study that provides novel and valuable data information about the relationship of leukocyte SIRT1 expression with diabetic pregnancy at the time of GDM diagnosis. First, we found significantly elevated leukocyte SIRT1 mRNA in a heterogeneous in regard to its expression group of hyperglycemic diabetic pregnancies, which correlated with glucose metabolism. It indicates that GDM affects alterations in SIRT1 at the level of its gene expression and it process is linked to changes in glucose homeostasis. Second, we documented the differential transcriptional response of leukocytes to SIRT1 over-abundance in GDM patients. Specifically, we found 11 genes with at least two-fold or more up-and down-regulated expression, which are engaged in biological processes implicated in the pathogenesis of T2DM. Hence, they might play a potentially important role in GDM-induced development of metabolic disturbances. Third, we confirmed a significant expression of four out of six genes identified by the PCR array approach in an extended GDM/SIRT1( $\uparrow)$ samples, indicating that moderate up-regulation of leukocyte SIRT1 expression (three-fold) in the hyperglycemic GDM/SIRT1(个) group works in concert with significant up-regulation (IL6, G6PD, and SNAP23) and down-regulation (ACLY) of diabetes-related genes involved in cell metabolism, inflammation, and molecular transport and trafficking. This is consistent with the conception that SIRT1 overexpression can reflect an adaptive/protective response to expression alterations of the aforementioned genes in leukocytes. Fourth, by using gene network and pathways analyses in SIRT1, IL6, G6PD, SNAP23, and ACLY genes, we revealed a potential role of several important biological processes and pathways mainly related to cellular and immunological processes, which may be engaged in changes of metabolic phenotypes of the GDM/SIRT1( $\uparrow)$ patients. However, further investigations in the future will be imperative in clarifying the functional and biological importance of these pathways in GDM. Fifth, by comparing leukocyte gene expression of the aforementioned four genes between the GDM/SIRT1( $\uparrow$ ) and GDM/SIRT1( $\leftrightarrow$ ) groups, we identified a unique ACLY under-expression in GDM/SIRT1( $\uparrow$ ) women, suggesting a biomarker candidate for further study. Of note, while it is not yet known how SIRT1 over-abundance might affect the decreased ACLY expression in hyperglycemic GDM patients, these results, though still exploratory, may represent a first step towards elucidating the beneficial influence of SIRT1 on ACL regulation under diabetic conditions. Hence, further investigations with the use of diabetic disease models are needed to clarify the underlying molecular mechanism of this effect. From a long-term perspective, this knowledge could help develop more effective therapies against diabetes.

Taken together, these findings are particularly important, as they indicate the relevance of diabetes-related gene expression pattern and pathways related to leukocyte SIRT1 overexpression in GDM and thereby provide insight into the transcriptomics of leukocytes in diabetic pregnancy. Although the expression pattern directs attention to cell metabolism, inflammation, and molecular transport and trafficking, functional validation of the identified genes is needed to establish their potential role in the development of GDM. 
Given the increasing prevalence of T2DM in women with a history of GDM, there is an urgent need to understand the molecular mechanisms underlying this phenomenon. In this context, intensive research on temporal quantitative leukocyte SIRT1 gene expression changes during pregnancy and the postpartum period after pregnancy complicated by GDM is currently under way in our group.

Supplementary Materials: Supplementary materials can be found at http:/ /www.mdpi.com/1422-0067/19/12/3826/s1.

Author Contributions: Data curation, K.M.-M. and A.Z.; Formal analysis, K.M.-M. and A.Z.; Investigation, K.M.-M.; Methodology, K.M.-M. and M.W.; Project administration, L.W. and M.W.; Resources, M.Z.-K. and K.C.; Supervision, L.W. and M.W.; Visualization, K.M.-M. and A.Z.; Writing—original draft, M.W.; Writing一review \& editing, L.W. and M.W. All authors read and approved the final manuscript.

Funding: This work was supported by a grant from the Medical University of Lodz (project no. 503/0-160-01/503-01-002-18).

Conflicts of Interest: The authors declare no conflict of interest.

\section{Abbreviations}

$\begin{array}{ll}\text { ACL } & \text { ATP citrate lyase } \\ \text { COX2 } & \text { Cyclooxygenase 2 } \\ \text { ECFC } & \text { Endothelial colony-forming cell } \\ \text { GDM } & \text { Gestational diabetes mellitus } \\ \text { G6PD } & \text { Glucose-6-phosphate dehydrogenase } \\ \text { HFD } & \text { High fat diet } \\ \text { HUVEC } & \text { Human umbilical vein endothelial cells } \\ \text { IL6 } & \text { Interleukin 6 } \\ \text { IPA } & \text { Ingenuity Pathway Analysis } \\ \text { MAPK } & \text { Mitogen-activated protein kinases } \\ \text { NGT } & \text { Normal glucose tolerance } \\ \text { SIRT1 } & \text { Sirtuin 1 } \\ \text { SNAP23 } & \text { Synaptosomal-associated protein } 23 \\ \text { STACs } & \text { Sirtuin-activating compounds } \\ \text { T2DM } & \text { Type 2 diabetes mellitus }\end{array}$

\section{References}

1. Coustan, D.R.; Lowe, L.P.; Metzger, B.E.; Dyer, A.R. The Hyperglycemia and Adverse Pregnancy Outcome (HAPO) study: Paving the way for new diagnostic criteria for gestational diabetes mellitus. Am. J. Obstet. Gynecol. 2010, 202, 654.e1-6. [CrossRef] [PubMed]

2. Forsbach-Sánchez, G.; Tamez-Peréz, H.E.; Vazquez-Lara, J. Diabetes and pregnancy. Arch. Med. Res. 2005, 36, 291-299. [CrossRef] [PubMed]

3. Shah, B.R.; Retnakaran, R.; Booth, G.L. Increased risk of cardiovascular disease in young women following gestational diabetes mellitus. Diabetes Care 2008, 31, 1668-1669. [CrossRef] [PubMed]

4. Bellamy, L.; Casas, J.P.; Hingorani, A.D.; Williams, D. Type 2 diabetes mellitus after gestational diabetes: A systematic review and meta-analysis. Lancet 2009, 373, 1773-1779. [CrossRef]

5. Kautzky-Willer, A.; Pacini, G.; Tura, A.; Bieglmayer, C.; Schneider, B.; Ludvik, B.; Prager, R.; Waldhäusl, W. Increased plasma leptin in gestational diabetes. Diabetologia 2001, 44, 164-172. [CrossRef] [PubMed]

6. Winkler, G.; Cseh, K.; Baranyi, E.; Melczer, Z.; Speer, G.; Hajós, P.; Salamon, F.; Turi, Z.; Kovács, M.; Vargha, P.; et al. Tumor necrosis factor system in insulin resistance in gestational diabetes. Diabetes Res. Clin. Pract. 2002, 56, 93-99. [CrossRef]

7. Retnakaran, R.; Hanley, A.J.; Raif, N.; Connelly, P.W.; Sermer, M.; Zinman, B. Reduced adiponectin concentration in women with gestational diabetes: A potential factor in progression to type 2 diabetes. Diabetes Care 2004, 27, 799-800. [CrossRef] [PubMed]

8. Lappas, M.; Hiden, U.; Froehlich, J.; Desoye, G.; Haugel-de Mouzon, S.; Jawerbaum, A. The role of oxidative stress in the pathophysiology of gestational diabetes mellitus. Antioxid. Redox Signal. 2011, 15, 3061-4100. [CrossRef] [PubMed] 
9. Wojcik, M.; Mac-Marcjanek, K.; Wozniak, L.A. Physiological and pathophysiological functions of SIRT1. Mini Rev. Med. Chem. 2009, 9, 386-394. [CrossRef] [PubMed]

10. Cao, Y.; Jiang, X.; Ma, H.; Wang, Y.; Xue, P.; Liu, Y. SIRT1 and insulin resistance. J. Diabetes Complicat. 2016, 30, 178-183. [CrossRef] [PubMed]

11. Banks, A.S.; Kon, N.; Knight, C.; Matsumoto, M.; Gutierrez-Juarez, R.; Rossetti, L.; Gu, W.; Accili, D. SirT1 gain of function increases energy efficiency and prevents diabetes in mice. Cell Metab. 2008, 8, 333-341. [CrossRef] [PubMed]

12. Pfluger, P.T.; Herranz, D.; Velasco-Miguel, S.; Serrano, M.; Tschöp, M.H. Sirt1 protects against high-fat diet-induced metabolic damage. Proc. Natl. Acad. Sci. USA 2008, 105, 9793-9798. [CrossRef] [PubMed]

13. De Kreutzenberg, S.V.; Ceolotto, G.; Papparella, I.; Bortoluzzi, A.; Semplicini, A.; Dalla Man, C.; Cobelli, C.; Fadini, G.P.; Avogaro, A. Down-regulation of the longevity-associated protein sirtuin 1 in insulin resistance and metabolic syndrome: Potential biochemical mechanisms. Diabetes 2010, 59, 1006-1015. [CrossRef] [PubMed]

14. Balestrieri, M.L.; Servillo, L.; Esposito, A.; D’Onofrio, N.; Giovane, A.; Casale, R.; Barbieri, M.; Paolisso, P.; Rizzo, M.R.; Paolisso, G.; et al. Poor glycaemic control in type 2 diabetes patients reduces endothelial progenitor cell number by influencing SIRT1 signalling via platelet-activating factor receptor activation. Diabetologia 2013, 56, 162-172. [CrossRef] [PubMed]

15. Baur, J.A.; Pearson, K.J.; Price, N.L.; Jamieson, H.A.; Lerin, C.; Kalra, A.; Prabhu, V.V.; Allard, J.S.; Lopez-Lluch, G.; Lewis, K.; et al. Resveratrol improves health and survival of mice on a high-calorie diet. Nature 2006, 444, 337-342. [CrossRef] [PubMed]

16. Milne, J.C.; Lambert, P.D.; Schenk, S.; Carney, D.P.; Smith, J.J.; Gagne, D.J.; Jin, L.; Boss, O.; Perni, R.B.; $\mathrm{Vu}, \mathrm{C} . \mathrm{B}$; et al. Small molecule activators of SIRT1 as therapeutics for the treatment of type 2 diabetes. Nature 2007, 450, 712-716. [CrossRef] [PubMed]

17. Qi, Y.; Davis, M.L.; Lainez, E.O.; Cote, A.M.; Johnson, M.O.; Gagne, D.J.; Vlasuk, G.P.; Ellis, J.L.; Suri, V. SRT2104, a novel small molecule SIRT1 activator ameliorates insulin resistance and promotes glucose utilization measured under a hyperinsulinemic-euglycemic clamp by enhancing both glycolysis and carbohydrate oxidation in mice fed a high fat diet. Diabetes 2011, 60 (Suppl. 1), 1007-P.

18. Liu, K.; Zhou, R.; Wang, B.; Mi, M.T. Effect of resveratrol on glucose control and insulin sensitivity: A meta-analysis of 11 randomized controlled trials. Am. J. Clin. Nutr. 2014, 99, 1510-1519. [CrossRef] [PubMed]

19. Pacholec, M.; Bleasdale, J.E.; Chrunyk, B.; Cunningham, D.; Flynn, D.; Garofalo, R.S.; Griffith, D.; Griffor, M.; Loulakis, P.; Pabst, B.; et al. SRT1720, SRT2183, SRT1460, and resveratrol are not direct activators of SIRT1. J. Biol. Chem. 2010, 285, 8340-8351. [CrossRef] [PubMed]

20. Timmers, S.; de Ligt, M.; Phielix, E.; van de Weijer, T.; Hansen, J.; Moonen-Kornips, E.; Schaart, G.; Kunz, I.; Hesselink, M.K.; Schrauwen-Hinderling, V.B.; et al. Resveratrol as add-on therapy in subjects with well-controlled type 2 diabetes: A randomized controlled trial. Diabetes Care 2016, 39, 2211-2217. [CrossRef] [PubMed]

21. Bordone, L.; Motta, M.C.; Picard, F.; Robinson, A.; Jhala, U.S.; Apfeld, J.; McDonagh, T.; Lemieux, M.; McBurney, M.; Szilvasi, A.; et al. 2006 Sirt1 regulates insulin secretion by repressing UCP2 in pancreatic beta cells. PLoS Biol. 2006, 4, e31. [CrossRef]

22. Frescas, D.; Valenti, L.; Accili, D. Nuclear trapping of the forkhead transcription factor FoxO1 via Sirt-dependent deacetylation promotes expression of glucogenetic genes. J. Biol. Chem. 2005, 280, 20589-20595. [CrossRef] [PubMed]

23. Gui, J.; Potthast, A.; Rohrbach, A.; Borns, K.; Das, A.M.; von Versen-Höynck, F. Gestational diabetes induces alterations of sirtuins in fetal endothelial cells. Pediatr. Res. 2016, 79, 788-798. [CrossRef] [PubMed]

24. Yao, L.; Wan, J.; Li, H.; Ding, J.; Wang, Y.; Wang, X.; Li, M. Resveratrol relieves gestational diabetes mellitus in mice through activating AMPK. Reprod. Biol. Endocrinol. 2015, 13, 118. [CrossRef] [PubMed]

25. Sultan, S.; Alzahrani, N.; Al-Sakkaf, K. The postpartum effect of maternal diabetes on the circulating levels of sirtuins and superoxide dismutase. FEBS Open Bio 2018, 8, 256-263. [CrossRef] [PubMed]

26. Moradipoor, S.; Ismail, P.; Etemad, A.; Wan Sulaiman, W.A.; Ahmadloo, S. Expression Profiling of Genes Related to Endothelial Cells Biology in Patients with Type 2 Diabetes and Patients with Prediabetes. BioMed Res. Int. 2016, 2016, 1845638. [CrossRef] [PubMed] 
27. Liew, C.C.; Ma, J.; Tang, H.C.; Zheng, R.; Dempsey, A.A. The peripheral blood transcriptome dynamically reflects system wide biology: A potential diagnostic tool. J. Lab. Clin. Med. 2006, 147, 126-132. [CrossRef] [PubMed]

28. Song, R.; Xu, W.; Chen, Y.; Li, Z.; Zeng, Y.; Fu, Y. The expression of Sirtuins 1 and 4 in peripheral blood leukocytes from patients with type 2 diabetes. Eur. J. Histochem. 2011, 2011, E10. [CrossRef] [PubMed]

29. Friebe, D.; Neef, M.; Kratzsch, J.; Erbs, S.; Dittrich, K.; Garten, A.; Petzold-Quinque, S.; Blüher, S.; Reinehr, T.; Stumvoll, M.; et al. Leucocytes are a major source of circulating nicotinamide phosphoribosyltransferase (NAMPT)/pre-B cell colony (PBEF)/visfatin linking obesity and inflammation in humans. Diabetologia 2011, 54, 1200-1211. [CrossRef] [PubMed]

30. Alcendor, R.R.; Gao, S.; Zhai, P.; Zablocki, D.; Holle, E.; Yu, X.; Tian, B.; Wagner, T.; Vatner, S.F.; Sadoshima, J. Sirt1 regulates aging and resistance to oxidative stress in the heart. Circ. Res. 2007, 100, 1512-1521. [CrossRef] [PubMed]

31. Grabowska, W.; Sikora, E.; Bielak-Zmijewska, A. Sirtuins, a promising target in slowing down the ageing process. Biogerontology 2017, 18, 447-476. [CrossRef] [PubMed]

32. Kwon, S.; Seok, S.; Yau, P.; Li, X.; Kemper, B.; Kemper, J.K. 2017 Obesity and aging diminish sirtuin 1 (SIRT1)-mediated deacetylation of SIRT3, leading to hyperacetylation and decreased activity and stability of SIRT3. J. Biol. Chem. 2017, 292, 17312-17323. [CrossRef] [PubMed]

33. Cohen, H.Y.; Miller, C.; Bitterman, K.J.; Wall, N.R.; Hekking, B.; Kessler, B.; Howitz, K.T.; Gorospe, M.; de Cabo, R.; Sinclair, D.A. Calorie restriction promotes mammalian cell survival by inducing the SIRT1 deacetylase. Science 2004, 305, 390-392. [CrossRef] [PubMed]

34. Nisoli, E.; Tonello, C.; Cardile, A.; Cozzi, V.; Bracale, R.; Tedesco, L.; Falcone, S.; Valerio, A.; Cantoni, O.; Clementi, E.; et al. Calorie restriction promotes mitochondrial biogenesis by inducing the expression of eNOS. Science 2005, 310, 314-317. [CrossRef] [PubMed]

35. Crujeiras, A.B.; Parra, D.; Goyenechea, E.; Martinez, J.A. Sirtuin gene expression in human mononuclear cells is modulated by caloric restriction. Eur. J. Clin. Investig. 2008, 38, 672-678. [CrossRef] [PubMed]

36. Engin-Ustun, Y.; Caglayan, E.K.; Kara, M.; Gocmen, A.Y.; Polat, M.F.; Aktulay, A. The effect of Ramadan fasting on sirtuin and visfatin levels. Interv. Med. Appl. Sci. 2016, 8, 14-19. [CrossRef] [PubMed]

37. Bori, Z.; Zhao, Z.; Koltai, E.; Fatouros, I.G.; Jamurtas, A.Z.; Douroudos, I.I.; Terzis, G.; Chatzinikolaou, A.; Sovatzidis, A.; Draganidis, D.; et al. The effects of aging, physical training, and a single bout of exercise on mitochondrial protein expression in human skeletal muscle. Exp. Gerontol. 2012, 47, 417-424. [CrossRef] [PubMed]

38. Huang, C.C.; Wang, T.; Tung, Y.T.; Lin, W.T. Effect of Exercise Training on Skeletal Muscle SIRT1 and PGC-1 $\alpha$ Expression Levels in Rats of Different Age. Int. J. Med. Sci. 2016, 13, 260-270. [CrossRef] [PubMed]

39. Hayashida, S.; Arimoto, A.; Kuramoto, Y.; Kozako, T.; Honda, S.; Shimeno, H.; Soeda, S. Fasting promotes the expression of SIRT1, an NAD+-dependent protein deacetylase, via activation of PPARa in mice. Mol. Cell. Biochem. 2010, 339, 285-292. [CrossRef] [PubMed]

40. Kaviarasan, S.; Muniandy, S.; Qvist, R.; Ismail, I.S. Gene expression profile in leukocytes of type 2 diabetic subjects. Biomed. Res. 2009, 20, 158-165. [CrossRef]

41. Manoel-Caetano, F.S.; Xavier, D.J.; Evangelista, A.F.; Takahashi, P.; Collares, C.V.; Puthier, D.; Foss-Freitas, M.C.; Foss, M.C.; Donadi, E.A.; Passos, G.A.; et al. Gene expression profiles displayed by peripheral blood mononuclear cells from patients with type 2 diabetes mellitus focusing on biological processes implicated on the pathogenesis of the disease. Gene 2012, 511, 151-160. [CrossRef] [PubMed]

42. Raatz, Y.; Ibrahim, S.; Feldmann, M.; Paleolog, E.M. Gene expression profiling and functional analysis of angiogenic markers in murine collagen induced arthritis. Arthritis Res. Ther. 2012, 14, R169. [CrossRef] [PubMed]

43. Colomiere, M.; Permezel, M.; Riley, C.; Desoye, G.; Lappas, M. Defective insulin signaling in placenta from pregnancies complicated by gestational diabetes mellitus. Eur. J. Endocrinol. 2009, 160, 567-578. [CrossRef] [PubMed]

44. Kuzmicki, M.; Telejko, B.; Szamatowicz, J.; Zonenberg, A.; Nikolajuk, A.; Kretowski, A.; Gorska, M. High resistin and interleukin-6 levels are associated with gestational diabetes mellitus. Gynecol. Endocrinol. 2009, 25, 258-263. [CrossRef] [PubMed] 
45. Morisset, A.S.; Dubé, M.C.; Côté, J.A.; Robitaille, J.; Weisnagel, S.J.; Tchernof, A. Circulating interleukin-6 concentrations during and after gestational diabetes mellitus. Acta Obstet. Gynecol. Scand. 2011, 90, 524-530. [CrossRef] [PubMed]

46. Ritchie, D.G. Interleukin 6 stimulates hepatic glucose release from prelabeled glycogen pools. Am. J. Physiol. 1990, 258, E57-E64. [CrossRef] [PubMed]

47. Tsigos, C.; Papanicolaou, D.A.; Kyrou, I.; Defensor, R.; Mitsiadis, C.S.; Chrousos, G.P. Dose-dependent effects of recombinant human interleukin-6 on glucose regulation. J. Clin. Endocrinol. Metab. 1997, 82, 4167-4170. [CrossRef] [PubMed]

48. Devaraj, S.; Venugopal, S.K.; Singh, U.; Jialal, I. Hyperglycemia induces monocytic release of interleukin-6 via induction of protein kinase $c-\alpha$ and $-\beta$. Diabetes 2005, 54, 85-91. [CrossRef] [PubMed]

49. Morohoshi, M.; Fujisawa, K.; Uchimura, I.; Numano, F. The effect of glucose and advanced glycosylation end products on IL-6 production by human monocytes. Ann. N. Y. Acad. Sci. 1995, 748, 562-570. [CrossRef] [PubMed]

50. Turek, I.A.; Wozniak, L.A.; Cypryk, K.; Wojcik, M. Hyperglycaemia-induced oxidative stress in gestational diabetes mellitus (GDM). Diabetol. Klin. 2015, 4, 189-198. [CrossRef]

51. Aslamy, A.; Thurmond, D.C. Exocytosis proteins as novel targets for diabetes prevention and/or remediation? Am. J. Physiol. Regul. Integr. Comp. Physiol. 2017, 312, R739-R752. [CrossRef] [PubMed]

52. Rezaei Farimani, A.; Saidijam, M.; Goodarzi, M.T.; Yadegar Azari, R.; Asadi, S.; Zarei, S.; Shabab, N. Effect of Resveratrol Supplementation on the SNARE Proteins Expression in Adipose Tissue of Stroptozotocin-Nicotinamide Induced Type 2 Diabetic Rats. Iran. J. Med. Sci. 2015, 40, 248-255. [PubMed]

53. Zhang, Z.; Apse, K.J.P.; Stanton, R.C. High glucose inhibits glucose 6-phosphate dehydrogenase via cAMP in aortic endo thelial cells. J. Biol. Chem. 2000, 275, 40042-40047. [CrossRef] [PubMed]

54. Xu, Y.; Osborne, B.W.; Stanton, R.C. Diabetes causes inhibition of glucose-6-phosphate dehydrogenase via activation of protein kinase A which contributes to oxidative stress in rat kidney cortex. Am. J. Physiol. Ren. Physiol. 2005, 289, F1040-F1047. [CrossRef] [PubMed]

55. Díaz-Flores, M.; Ibáñez-Hernández, M.A.; Galván, R.E.; Gutiérrez, M.; Durán-Reyes, G.; Medina-Navarro, R.; Pascoe-Lira, D.; Ortega-Camarillo, C.; Vilar-Rojas, C.; Cruz, M.; et al. Glucose-6-phosphate dehydrogenase activity and NADPH/NADP1 ratio in liver and pancreas are dependent on the severity of hyperglycemia in rat. Life Sci. 2006, 78, 2601-2607. [CrossRef] [PubMed]

56. Zhang, Z.; Yang, Z.; Zhu, B.; Hu, J.; Liew, C.W.; Zhang, Y.; Leopold, J.A.; Handy, D.E.; Loscalzo, J.; Stanton, R.C. Increasing glucose 6-phosphate dehydrogenase activity restores redox balance in vascular endothelial cells exposed to high glucose. PLoS ONE 2012, 7, e49128. [CrossRef] [PubMed]

57. Kuznetsova, L.A.; Chistiakova, O.V. The regulation of glucose-6-phosphate dehydrogenase and glycogen synthase activities by insulin superfamily peptides in myometrium of pregnant women and its impairments under different types of diabetes mellitus. Biomed. Khim. 2009, 55, 663-672. [CrossRef] [PubMed]

58. Heymann, A.D.; Cohen, Y.; Chodick, G. 2012 Glucose-6-phosphate dehydrogenase deficiency and type 2 diabetes. Diabetes Care 2012, 35, e58. [CrossRef] [PubMed]

59. Yazgan, Ü.C.; Taşdemir, E.; Bilgin, H.M.; Deniz Obay, B.; Şermet, A.; Elbey, B. Comparison of the anti-diabetic effects of resveratrol, gliclazide and losartan in streptozotocin-induced experimental diabetes. Arch. Physiol. Biochem. 2015, 121, 157-161. [CrossRef] [PubMed]

60. Gribble, A.D.; Ife, R.J.; Shaw, A.; McNair, D.; Novelli, C.E.; Bakewell, S.; Shah, V.P.; Dolle, R.E.; Groot, P.H.; Pearce, N.; et al. ATP-Citrate lyase as a target for hypolipidemic intervention. 2. Synthesis and evaluation of $(3 R, 5 S)$-omega-substituted-3-carboxy-3,5-dihydroxyalkanoic acids and their gamma-lactone prodrugs as inhibitors of the enzyme in vitro and in vivo. J. Med. Chem. 1998, 41, 3582-3595. [CrossRef] [PubMed]

61. Wang, Q.; Jiang, L.; Wang, J.; Li, S.; Yu, Y.; You, J.; Zeng, R.; Gao, X.; Rui, L.; Li, W.; et al. Abrogation of hepatic ATP-citrate lyase protects against fatty liver and ameliorates hyperglycemia in leptin receptor-deficient mice. Hepatology 2009, 49, 1166-1175. [CrossRef] [PubMed]

62. Chypre, M.; Zaidi, N.; Smans, K. ATP-citrate lyase: A mini-review. Biochem. Biophys. Res. Commun. 2012, 422, 1-4. [CrossRef] [PubMed]

63. Wellen, K.E.; Hatzivassiliou, G.; Sachdeva, U.M.; Bui, T.V.; Cross, J.R.; Thompson, C.B. ATP-citrate lyase links cellular metabolism to histone acetylation. Science 2009, 324, 1076-1080. [CrossRef] [PubMed] 
64. Kim, Y.M.; Shin, H.T.; Seo, Y.H.; Byun, H.O.; Yoon, S.H.; Lee, I.K.; Hyun, D.H.; Chung, H.Y.; Yoon, G. Sterol regulatory element-binding protein (SREBP)-1-mediated lipogenesis is involved in cell senescence. J. Biol. Chem. 2010, 285, 29069-29077. [CrossRef] [PubMed]

65. Hata, K.; Andoh, A.; Shimada, M.; Fujino, S.; Bamba, S.; Araki, Y.; Okuno, T.; Fujiyama, Y.; Bamba, T. IL-17 stimulates inflammatory responses via NF-kappaB and MAP kinase pathways in human colonic myofibroblasts. Am. J. Physiol. Gastrointest. Liver Physiol. 2002, 282, G1035-G1044. [CrossRef] [PubMed]

66. Zhang, Z.; Andoh, A.; Inatomi, O.; Bamba, S.; Takayanagi, A.; Shimizu, N.; Fujiyama, Y. Interleukin-17 and lipopolysaccharides synergistically induce cyclooxygenase-2 expression in human intestinal myofibroblasts. J. Gastroenterol. Hepatol. 2005, 20, 619-627. [CrossRef] [PubMed]

67. Grover, M.; Gibbons, S.J.; Nair, A.A.; Bernard, C.E.; Zubair, A.S.; Eisenman, S.T.; Wilson, L.A.; Miriel, L.; Pasricha, P.J.; Parkman, H.P.; et al. Transcriptomic signatures reveal immune dysregulation in human diabetic and idiopathic gastroparesis. BMC Med. Genom. 2018, 11, 62. [CrossRef] [PubMed]

68. Radaelli, T.; Varastehpour, A.; Catalano, P.; Hauguel-de Mouzon, S. Gestational diabetes induces placental genes for chronic stress and inflammatory pathways. Diabetes 2003, 52, 2951-2958. [CrossRef] [PubMed]

69. Zhao, Y.H.; Wang, D.P.; Zhang, L.L.; Zhang, F.; Wang, D.M.; Zhang, W.Y. Genomic expression profiles of blood and placenta reveal significant immune-related pathways and categories in Chinese women with gestational diabetes mellitus. Diabet. Med. 2011, 28, 237-246. [CrossRef] [PubMed]

70. The Polish Diabetes Association 2011. Clinical recommendations for the management of patients with diabetes. Diabetol. Prakt. 2011, 12 (Suppl. A), A1-A46.

71. Wojcik, M.; Zieleniak, A.; Mac-Marcjanek, K.; Wozniak, L.A.; Cypryk, K. The elevated gene expression level of the $\mathrm{A}(2 \mathrm{~B})$ adenosine receptor is associated with hyperglycemia in women with gestational diabetes mellitus. Diabetes Metab. Res. Rev. 2014, 30, 42-53. [CrossRef] [PubMed]

72. Wojcik, M.; Zieleniak, A.; Zurawska-Klis, M.; Cypryk, K.; Wozniak, L.A. Increased expression of immune-related genes in leukocytes of patients with diagnosed gestational diabetes mellitus (GDM). Exp. Biol. Med. 2016, 241, 457-465. [CrossRef] [PubMed]

73. Matthews, D.R.; Hosker, J.P.; Rudenski, A.S.; Naylor, B.A.; Treacher, D.F.; Turner, R.C. 1985 Homeostasis model assessment: Insulin resistance and $\beta$-cell function from fasting plasma glucose and insulin concentrations in man. Diabetologia 1985, 28, 412-419. [CrossRef] [PubMed]

74. Siegel, S.; Castellan, N.J. Nonparametric Statistics for the Behavioral Sciences, 2nd ed.; International ed.; McGraw-Hill: New York, NY, USA, 1988; p. 399. 